\title{
EDUCATION AND MIGRATION AMONG NOVA SCOTIA YOUTH: SOME SEX DIFFERENCES
}

\author{
Helen Ralston \\ Saint Mary's University, Halifax, Nova Scotia, Canada
}

Résumé - L'analyse longitudinale de la différenciation sexuelle dans les relations entre l'éducation et la migration parmi les jeunes de la Nouvelle Ecosse, révèle que les aspirations éducationelles post-secondaires et l'actuelle réalisation post-secondaire sont apparentées d'une manière significative à la migration parmi les hommes mais non pas parmi les femmes. En comparaison des jeunnes femmes, les jeunes hommes ont tendance à continuer leur éducation davantage, à émigrer plus loin et à fréquenter des universités et des institutions technologiques; tandis qu'au contraire, les femmes fréquentent les institutions qui offrent des formations convenables aux professions traditionelles des femmes se trouvant dans leur communauté originale ou en dedans la province. Les résultats indiquent que les filles adolescentes qui aspirent aux professions traditionnelles des femmes trouvent que la structure de chanches locale est convenable à leurs buts; que le mariage comme un but professionnel pour les femmes peut être un facteur moteur en ce qui concerne la migration et peut en effet expliquer différenciation sexuelle en taux et en nature d'instruction et les motifs pour la migration.

Abstract - Longitudinal analysis of sex differences in the relationships between education and migration among Nova Scotia youth reveals that post-secondary educational aspirations and actual post-secondary attainment are significantly related to migration among males but not among females. As compared to young women, young men tend to continue their education more, to migrate greater distances, and to attend universities and technology institutions; whereas women attend institutions leading to traditional women's occupations, located in their origin communities or within the province. The results indicate that adolescent girls aspiring to traditional women's occupations find the local opportunity structure suitable for their goals; that marriage as a career goal for women may be a positive motivating factor for migration and may in fact explain sex differences in rates and kinds of schooling and motives for migration.

Key words - longitudinal analysis, education, migration, opportunity structure, sex differences

\section{Introduction}

This paper is a longitudinal analysis of the migration process among a specific sub-group of the Canadian population: young adults, relatively-highly educated, virtually all of British Isles ethnic origin - in other words, the most highly mobile group of the population (cf. Stone, 1974:277). Furthermore, the paper addresses itself to significant differences between young men and young women in the migration process. Despite considerable study of patterns of internal migration in Canada, to my knowledge, little or no attention has been paid to analysis of migration among women. Moreover, little research explores the educational patterns of women, as distinct from those of men. The present paper focuses on both of these problems.

The purpose of the study is to examine and to attempt to offer a sociological explanation for sex differences in the relationship between educational intentions and subsequent migrant status. The research is longitudinal, being based on a re-study in 1972 of a sample of three hundred and nintey-one respondents drawn from the seventeen Nova Scotia public high schools included in the Career Decisions Project conducted in the 1965-66 academic year. The sample is representative of the population of secondary school students in publicly-operated Nova Scotia high schools of 1965-66.' 
Helen Ralston

\section{Conceptual Framework}

In an early attempt to explain migration from a sociological perspective, Thomas (1938) conceptualized it as a pattern of behaviour directed towards the pursuit of goals perceived as unattainable in the community of origin but attainable elsewhere. She later (1941) developed the push-pull hypothesis to analyse and explain migration in terms of certain factors "pushing" persons away from the area of origin and "pulling" them to the area of destination.

Stouffer (1940) introduced the concept of opportunities to account for the pull towards destinations of greater opportunity; he also noted (1960) the singular attractiveness of the capital city and larger urban centres, regardless of the number of intervening opportunities. Various empirical studies of the educational aspirations of rural and urban youth have adopted the perspective that urban society offers greater opportunities for the attainment of higher career goals. The evidence suggests that structural characteristics of the rural environment "limit" the aspirations of rural youth. Limited educational programmes, more limited information on the range of occupational choices available to the rural youth (cf. Schwarzweller, 1959; Hall and McFarlane, 1962; Sewell and Orenstein, 1965; Whyte, 1967; Breton and McDonald, 1967; Pike, 1970; Breton, 1972; Synge, 1977). Some of these studies note sex differences in aspirations and migration, but they make little or no attempt to explain the differences. Other studies (cf. Goldsmith, 1962; Connor, 1963; Lee, 1966; Taylor, 1969) have stressed that an adequate explanation of migration in terms of the pursuit of goals must take into account not only the objective structural conditions in the areas of origin and destination but also the orientations of the potential migrants to the objective situation, their perceptions of reality.

It is my argument that an adolescent in high school is oriented towards certain career goals. The career may be perceived by the individual as a means to a goal of success, prestige, income, social mobility, a life style, or as an end in itself. The pursuit of a desired career, for the most part, requires some type of post-secondary education or training, to be obtained in one's home community or elsewhere. It seems reasonable to assume that the career decision and the related educational decision for both males and females, though somewhat different for the two sexes, precede the migration process. The assumption is particularly defensible in the present longitudinal research, since it focuses on young persons who expressed post-secondary educational aspirations as high school students in 1965, who attained a certain educational level in 1972, and who were residentially stable or geographically mobile in the intervening seven years. Actual migration is a mode of behaviour directed to the attainment of the desired goal - the education or training for a career, the career itself or the specific goals sought through the career-means.

In the process of formulating an educational plan and a career goal, the adolescent matches himself or herself and the environment in relationship to future attainments. The adolescent's perception of the future, his or her assessment of the opportunities available in the community of origin or elsewhere, and his or her subsequent decisions and actions depend to a large degree on the objective structural conditions (cf. DeJong and Ahmad, 1976: 276). A problem arises, however, when one tries to analyse the process of migratory decision-making. Not only must one attempt to account for the reasons why some persons exposed to similar sets of conditions actually migrate while others do not, but one must also establish a method of measuring motives for behaviour. Taylor (1969) has suggested a model that combines two alternative approaches to the analysis of migratory decision-making: (1) to do a survey and accept the migrants' own statements of motives for migration; (2) to infer motives for migration from a study of objective structural determinants in the areas of origin and destination and then to impute motives to the migrants. There are difficulties (which Taylor acknowledges) in each of these approaches. Where one accepts the migrant's own account of motives, one encounters the difficulty of distinguishing between "real" and "stated" motives and the further problem of the migrant's rationalization of the decision when cognitive dissonance has resulted from a choice between two 
alternatives (Festinger, 1957:100). On the other hand, when one imputes motives for migration on the basis of inference from structural factors, there tends to be an over-emphasis on the rational element in the decision to migrate, to the neglect of differential perception and evaluation of objective factors (1969: 99). Taylor's model is of value in that he has drawn attention to the need for consideration of both objective structural conditions in the social context of the individual (the potential migrant) and the subjective aspects of the individual's point of view (cf. Davis, 1949: 586). My own study, in that it is longitudinal, minimizes the dissonance problem.

$I$ argue in this study that the issue of post-secondary educational aspirations is different for adolescent boys and girls. The analysis of the original Breton Career Decisions Project is based on the assumption that the basic decision for the girl is whether or not to pursue a career outside the home, either before or after her marriage, only before marriage, or not at all (Breton, 1972: 279-294). Breton found that girls who intended to pursue a career outside the home were somewhat more likely to plan to continue to post-secondary school than others, and were likely to express a preference for a professional occupation (Breton, 1972: 293). For many young women, marriage itself is an important goal, a career choice in fact. For some young women, moreover, the goal of success, prestige, income, social mobility, or a life-style is perceived as being achieved by the career of the husband rather than by the woman herself (cf. Turner, 1964: 271-285). For young men, on the other hand, pursuit of a career both before and after marriage is normative in our society; hence they are more likely to aspire to post-secondary education or training related to the career goal.

The evidence also suggests that the objective structural conditions with respect to postsecondary education and careers are in fact different for young men and for young women. The school prepares girls better than boys for the kind of occupational world they shall enter as adults; the skills learned in school are more readily transferable to women's occupations of teaching, nursing, and various clerical occupations; post-secondary training facilities (for teaching, nursing, business) are more readily available than the kind of post-secondary schools boys are more likely to need for the man's occupational world (cf. Hall and McFarlane, 1962; Pyke, 1977; Stephenson, 1977). This line of argument is based on the assumption that there is in fact a different occupational world for the young woman and the young man (and therefore different kinds of post-secondary institutions where men and women can prepare for their respective careers). Though one might challenge these assumptions, nevertheless there is abundant evidence in the social science literature documenting sexual division of labour and the fact that there are certain "jobs for women" (cf. Marchak, 1977; Meissner, 1977). There is also some evidence of the influence of sexual differentiation in the occupational structure of communities on the migration process (cf. Lucas, 1971: 354-357).

The general hypothesis of the research may be stated as follows: The educational and career aspirations of youth influence their migrant status as young adults. The specific questions I address in this paper are: What are the sex differences in the relationship between educational aspirations and migration, and how can one account for these differences? What are the educational patterns of the geographically mobile and the geographically stable, and how do they differ for males and females?

\section{Methods of data collection and analysis}

To collect the longitudinal data necessary to achieve the objectives of the present study, the sample of 391 Nova Scotia respondents to the original Breton project had to be traced. The initial data were obtained from questionnaires administered to students in school; the respondents were identified by school, name, sex, age, and grade in 1965 . With the permission of the Nova Scotia Department of Education, a feasibility study was carried out during the last weeks of May, 1972. In this phase of the study, the researcher visited each of the seventeen 
schools of the province involved in the study and enlisted the help of the principals and school staff concerned to obtain current addresses of the respondents through school records, knowledge of respondents, personal contact of family, relatives and/or friends. Not all respondents were traced in this initial visit of the communities of origin, but a sufficiently high proportion (approximately 70 per cent) was located to indicate that the longitudinal study would be feasible.

The data were collected principally in interviews bewteen August and November, 1972; of the three hundred and ninety one respondents in the sample, three hundred and forty six (88.5 per cent) were interviewed. Mailed questionnaires were completed by thirty five ( 9 per cent) of the respondents; three persons, after being contacted, failed to return mailed questionnaires (or failed to receive them); three persons could not be found, although their community of residence was known; four persons had died since the original survey of 1965 . The method of interviewing respondents also gave observational data regarding the communities of residence of both migrants and non-migrants.

To operationalize the variables, items were taken from both the fall questionnaire of Breton's 1965 study and from my own follow-up questionnaire of 1972 . In the 1972 study the aim was to explain the migrant status of young persons in terms of their educational aspirations as adolescents. Items in the 1972 questionnaire, therefore, were used as operational definitions of the dependent variable, migrant status; items in Breton's fall 1965 questionnaire were used to test the influence of educational plans at that time on subsequent migrant status. The adolescent's educational plans in 1965 were assessed by asking the following question: "Do you think you will continue your education after high school on a full-time basis, on a part-time basis, or not at all?" Those respondents who stated that they would continue their education definitely or probably full-time, and definitely or probably part-time were classified as aspiring to postsecondary education. Respondents who fell in none of these categories were classfied as not aspiring to post-secondary education.

A single item in the 1972 study was used to measure migrants' motives for migration. The migrants were asked to respond to the following statement: "People move away from the place they grew up in for different reasons. What was your main reason for moving away from (place of residence in 1965-66)?" The possible response categories included, "To continue my education." In addition, objective data on the opportunities for post-secondary education in the communities of origin were independently gathered.

Since the level of measurement established for the dependent variable (migrant status) was nominal and that for the major independent variables (with a few exceptions) was nominal or ordinal, bi-variate and multi-variate contingency tables were used for data analysis. Analysis was both facilitated and limited by the measures of association and tests of significance available in the packaged computer programme used to merge the 1965 and 1972 data sets.

\section{Definition of migration}

As Stone (1974: 267) has noted, there is no real consensus as to what is the most useful definition of migration (cf. Elizaga, 1972: 122-125). For the purposes of the present study, in common with Statistics Canada usage, municipal boundaries are the defining characteristic for distinguishing between migrants and the larger category of movers, who may have moved short distances within the same town or county. Migration refers to those changes of residence that involve crossing municipal boundaries. In contrast to Statistics Canada practice, however, and in common with other demographic research (cf. Simmons and Ramiro, 1972; Claser and Habers, 1974), the present study takes account of those persons who have moved out of the municipality within the seven-year period (in this case, 1965 to 1972), but who have returned to reside in the 
community of residence in 1965, and classifies such persons as return migrants. In this research, non-migrants are defined as persons who are living in the same town or county in 1972 in which they lived in 1965, and who have not moved from that town or county in the intervening seven years. Moreover, persons are classified as migrants whether they made the basic decision for themselves or their families, or whether their migration was merely derivative from a decision made by parents or spouse. ${ }^{2}$ Finally, persons who migrated as students to continue their education are also classified as true migrants; in other words, the student, defined as a migrant, is assumed to be an active decision-making migrant, even though parents or significant others may have influenced the decision to migrate.

\section{Findings}

The data show that migrants comprise approximately 45 per cent of the total sample; return migrants, approximately 19 per cent; non-migrants approximately 36 per cent. This simple classification of the respondents shows that there are differences between males and females. There is a slightly higher ( 3.5 per cent) proportion of migrant males than migrant females. These findings are presented in Table 1 . The data confirm the general patterns of migration in Canada. The vast majority of migrants are intra-provincial migrants (about half among both males and females); a further 5 per cent of the sample have migrated to contiguous provinces within the Atlantic region. Males are represented in slightly higher proportions than females among inter-provincial migrants to provinces outside the Atlantic region, suggesting that females may find attainment of their goals nearer to home than the males. On the other hand, three young women among the few international migrants have provided interesting case studies of migration motives and career plans in the form of long personal letters accompanying their mailed questionnaires; these data suggest that for this small segment of the sample the search for opportunity implied a successful career that was measured less in terms of monetary reward or prestige than personal commitment to public social issues.

The respondents also show sex differences in terms of a basic structural variable: size of 1972 community of residence. The definition of community size conforms to census usage. Since a large proportion (approximately one-third) of the respondents resides in 1972 in metropolitan Halifax-Dartmouth, this community is separately identified. Table 2 presents sex differentials in the distribution of respondents by size of 1972 community of residence. Whereas almost half the respondents in 1972 reside in metropolitan areas, a greater proportion of males than of females is in metropolitan centres, and males have migrated in greater numbers to metropolitan centres outside the province. In the interpretation of these data, however, the sample skew in terms of male/female distribution by community of origin must also be taken into account. In the original Breton study, only one-third of the respondents were metropolitan residents, but males were much more heavily represented than females ( 58 per cent males, as compared to 42 per cent females); the proportion was exactly reversed for residence in communities of less than 10,000 population ( 42 per cent males, and 58 per cent females). The impression that males may have been more migratory than females in terms of moving from small towns and rural areas to the larger urban and metropolitan centres is confirmed by the longitudinal data in Table 3 which show that 63 per cent of the males and 54 per cent of the females who resided in communities of less than one thousand population migrated. Migration is least evident among those who resided in 1965 in metropolitan Halifax-Dartmouth, but whatever the size of community or origin, migration is greater among males than among females. These data suggest that respondents residing in smaller communities with fewer educational and job opportunities have migrated to communities with a more favourable opportunity structure. Young persons residing in the metropolitan area, with a number of alternative post-secondary schools and a broad range of job opportunities, have tended to remain geographically stable. If they have migrated (for 
Helen Ralston

TABLE 1. PERCENTAGE DISTRIBUTION OF RESPONDENTS CLASSIFIED AS MIGRANTS, RETURN MIGRANTS, AND NON-MIGRANTS, BY SEX

\begin{tabular}{|c|c|c|c|}
\hline Migrant Status & Male & Female & Tota1 \\
\hline \multicolumn{4}{|l|}{ Migrant } \\
\hline Intra-provincial migrant & $\begin{array}{l}22.3 \% \\
(41)\end{array}$ & $\begin{array}{r}23.2 \% \\
(47)\end{array}$ & $\begin{array}{r}22.7 \% \\
(88)\end{array}$ \\
\hline $\begin{array}{l}\text { Other Atlantic inter- } \\
\text { provincial migrant }\end{array}$ & $\begin{array}{l}6.0 \\
(11)\end{array}$ & $\begin{array}{l}4.4 \\
(9)\end{array}$ & $\begin{array}{l}5.2 \\
(20)\end{array}$ \\
\hline $\begin{array}{l}\text { Other Canadian inter- } \\
\text { provincial migrant }\end{array}$ & $\begin{array}{c}17.4 \\
(32)\end{array}$ & $\begin{array}{r}13.3 \\
(27)\end{array}$ & $\begin{array}{r}15.2 \\
(59)\end{array}$ \\
\hline International migrant & $\begin{array}{c}1.6 \\
(3)\end{array}$ & $\begin{array}{l}2.9 \\
(6)\end{array}$ & $\begin{array}{c}2.3 \\
(9)\end{array}$ \\
\hline Total migrant & $\begin{array}{r}47.3 \% \\
(87)\end{array}$ & $\begin{array}{r}43.8 \% \\
(89)\end{array}$ & $\begin{array}{l}45.4 \% \\
(176)\end{array}$ \\
\hline Return migrant & $\begin{array}{l}17.9 \\
(33)\end{array}$ & $\begin{array}{r}19.7 \\
(40)\end{array}$ & $\begin{array}{r}18.9 \\
(73)\end{array}$ \\
\hline Non-migrant & $\begin{array}{c}34.8 \\
(65)\end{array}$ & $\begin{array}{l}36.5 \\
(73)\end{array}$ & $\begin{array}{l}35.7 \\
(138)\end{array}$ \\
\hline Total & $\begin{array}{c}100.0 \% \\
(185)\end{array}$ & $\begin{array}{l}100.0 \% \\
(202)\end{array}$ & $\begin{array}{c}100.0 \% \\
(387)\end{array}$ \\
\hline
\end{tabular}

post-secondary education, job training and experience, or for other reasons), both males and females originally residing in Halifax-Dartmouth have tended to return in relatively high proportions (19 per cent for both sexes). On the other hand, it is the young women who have returned to the smaller communities in relatively high proportions. These young women may have returned home to marry, or to find jobs (perhaps nursing, clerical or sales jobs) in a local occupational-structure more suitable to young women-than to young men.

The original Breton sample was also skewed in terms of male/female distribution by age. All the respondents are young adults at the time of the 1972 study, ranging in age from 19 years to 28 years, the median age being 22.8 years and the mode being 22 years. Females, however, are somewhat younger than males, the modes being 22 years and 24 years respectively; and 74 per cent of the females fall in the younger age-category of 23 years and less, whereas only 56 per cent of the males fall in this younger age category. Tables 4 and 5 present the findings with respect to migrant status and the selected personal characteristics of age and marital status, respectively. Looking at the sample as a whole in terms of its age-sex structure, we find a 41 per cent-male/59 per cent-female distribution in the younger age category, and a 60 per centmale/ 40 per cent-female distribution in the older age category. One might expect this fact to be significant for marriage patterns as well as for migration. 
Education and Migration Among Nova Scotia Youth

TABLE 2. PERCENTAGE DISTRIBUTION OF RESPONDENTS BY SIZE OF COMMUNITY OF RESIDENCE, 1972, BY SEX

\begin{tabular}{l|c|c|c}
\hline \hline $\begin{array}{l}\text { Size of community } \\
\text { of residence }\end{array}$ & Males & Females & Total \\
\hline $\begin{array}{l}\text { Over 100,000 } \\
\text { (metro Hfx.-Dartmouth) }\end{array}$ & $35.6 \%$ & $30.8 \%$ & $33.1 \%$ \\
$\begin{array}{l}\text { Over 100,000 } \\
\text { (other metro) }\end{array}$ & 14.6 & $(62)$ & $(128)$ \\
$10,000-99,999$ & $(27)$ & 10.0 & 12.2 \\
& 9.2 & 13.9 & $(47)$ \\
$1,000-9,999$ & $(17)$ & $(28)$ & 11.7 \\
& 21.1 & 18.9 & $(45)$ \\
Less than 1,000 & $(39)$ & $(38)$ & 19.9 \\
& 19.5 & 26.4 & $(77)$ \\
\hline Total & $(36)$ & $(53)$ & 23.1 \\
& $100.0 \%$ & $100.0 \%$ & $(89)$ \\
\hline
\end{tabular}

TABLE 3. MIGRANT STATUS, 1972, BY SIZE OF COMMUNITY OF ORIGIN, 1965, BY SEX

\begin{tabular}{|c|c|c|c|c|c|c|c|c|c|c|c|c|}
\hline \multirow{3}{*}{$\begin{array}{l}\text { Iifigrant } \\
\text { status }\end{array}$} & \multicolumn{12}{|c|}{ Size of community of origin } \\
\hline & \multicolumn{3}{|c|}{100,000 or more } & \multicolumn{3}{|c|}{$10,000-99,000$} & \multicolumn{3}{|c|}{$1,000-9,999$} & \multicolumn{3}{|c|}{ Less than 1,000} \\
\hline & $M$ & $\mathrm{~F}$ & $\mathrm{~T}$ & $M$ & $\bar{F}$ & $\mathrm{~T}$ & $M$ & F & $\mathrm{T}$ & M & F & $T$ \\
\hline Migrant & $\begin{array}{l}34.2 \% \\
(25)\end{array}$ & $\begin{array}{l}28.3 \% \\
(15)\end{array}$ & $\begin{array}{l}31.7 \% \\
(40)\end{array}$ & $\begin{array}{c}53.3 \% \\
(8)\end{array}$ & $\begin{array}{c}42.8 \% \\
(6)\end{array}$ & $\begin{array}{l}48.3 \% \\
(14)\end{array}$ & $\begin{array}{l}45.0 \% \\
\text { (18) }\end{array}$ & $\begin{array}{l}44.0 \% \\
(22)\end{array}$ & $\begin{array}{l}44.4 \% \\
(40)\end{array}$ & $\begin{array}{l}63.1 \% \\
(36)\end{array}$ & $\begin{array}{l}54.1 \% \\
(46)\end{array}$ & $\begin{array}{l}57.7 \% \\
(82)\end{array}$ \\
\hline Return migrant & $\begin{array}{l}19.2 \% \\
(14)\end{array}$ & $\begin{array}{l}18.9 \% \\
(10)\end{array}$ & $\begin{array}{l}19.1 \% \\
(24)\end{array}$ & $\begin{array}{l}26.7 \% \\
\text { (4) }\end{array}$ & $\begin{array}{c}28.6 \% \\
(4)\end{array}$ & $\begin{array}{c}27.6 \% \\
(8)\end{array}$ & $\begin{array}{c}15.0 \% \\
(6)\end{array}$ & $\begin{array}{l}24.0 \% \\
(12)\end{array}$ & $\begin{array}{l}20.0 \% \\
(18)\end{array}$ & $\begin{array}{c}15.8 \% \\
(9)\end{array}$ & $\begin{array}{l}16.5 \% \\
(14)\end{array}$ & $\begin{array}{l}16.2 \% \\
(23)\end{array}$ \\
\hline Non-migrant & $\begin{array}{l}46.6 \% \\
(34)\end{array}$ & $\begin{array}{l}52.8 \% \\
(28)\end{array}$ & $\begin{array}{l}49.2 \% \\
(62)\end{array}$ & $\begin{array}{c}20.0 \% \\
(3)\end{array}$ & $\begin{array}{c}28.6 \% \\
(4)\end{array}$ & $\begin{array}{c}24.1 \% \\
(7)\end{array}$ & $\begin{array}{l}40.0 \% \\
(16)\end{array}$ & $\begin{array}{l}32.0 \% \\
(16)\end{array}$ & $\begin{array}{l}35.6 \% \\
(32)\end{array}$ & $\begin{array}{l}21.1 \% \\
(12)\end{array}$ & $\begin{array}{l}29.4 \% \\
(25)\end{array}$ & $\begin{array}{l}26.1 \% \\
(37)\end{array}$ \\
\hline Total & $\begin{array}{c}100.0 \% \\
(73) \\
57.9 \%\end{array}$ & $\begin{array}{c}100.0 \% \\
(53) \\
42.1 \%\end{array}$ & $\begin{array}{l}100.0 \% \\
(126) \\
100.0 \%\end{array}$ & $\begin{array}{c}100.0 \% \\
(15) \\
51.7 \%\end{array}$ & $\begin{array}{c}100.0 \% \\
(14) \\
48.3 \%\end{array}$ & $\begin{array}{c}100.0 \% \\
(29) \\
100.0 \%\end{array}$ & $\begin{array}{c}100.0 \% \\
(40) \\
44.4 \%\end{array}$ & $\begin{array}{c}100.0 \% \\
(50) \\
55.6 \%\end{array}$ & $\begin{array}{c}100.0 \% \\
(90) \\
100.0 \%\end{array}$ & $\begin{array}{c}100.0 \% \\
(57) \\
40.1 \%\end{array}$ & $\begin{array}{c}100.0 \% \\
(85) \\
59.9 \%\end{array}$ & $\begin{array}{l}100.0 \% \\
(142) \\
100.0 \%\end{array}$ \\
\hline
\end{tabular}

For toal sample: Chi-square $=23.00067$ ksk $\quad$ d.f. $=6 \quad c=.23685$

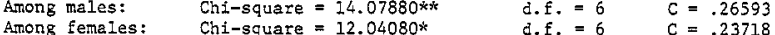

Level of significance: $* .10 ; * * .05 ; * * * .02 ; * * * * .01 ; * * * * * .001$. This notation will be used in all tables in future. No asterisk indicates that the chi-square value obtained is not significant. C represents Pearson's contingency Coefficient, which adjusts chi-square for chi-squate plus $N$. Its formula is: $c=\sqrt{\frac{x^{2}}{x^{2}+\mathbb{N}}}$ 
Helen Ralston

TABLE 4. AGE OF RESPONDENTS BY MIGRANT STATUS

\begin{tabular}{|c|c|c|c|c|c|c|}
\hline \multirow{2}{*}{$\begin{array}{l}\text { Migrant } \\
\text { Status }\end{array}$} & \multicolumn{6}{|c|}{ Age } \\
\hline & \multicolumn{3}{|c|}{$19-23$ years } & \multicolumn{3}{|c|}{$24-28$ years } \\
\hline & M & F & $T$ & M & $\mathrm{F}$ & $T$ \\
\hline Migrant & $\begin{array}{l}50.5 \% \\
(52)\end{array}$ & $\begin{array}{l}43.6 \% \\
(65)\end{array}$ & $\begin{array}{l}46.4 \% \\
(117)\end{array}$ & $\begin{array}{l}42.0 \% \\
(34)\end{array}$ & $\begin{array}{l}45.3 \% \\
(24)\end{array}$ & $\begin{array}{l}43.3 \% \\
(58)\end{array}$ \\
\hline $\begin{array}{l}\text { Return } \\
\text { migrant }\end{array}$ & $\begin{array}{l}18.4 \\
(19)\end{array}$ & $\begin{array}{l}20.8 \\
(31)\end{array}$ & $\begin{array}{l}19.9 \\
(50)\end{array}$ & $\begin{array}{l}17.3 \\
(14)\end{array}$ & $\begin{array}{c}17.0 \\
(9)\end{array}$ & $\begin{array}{l}17.2 \\
(23)\end{array}$ \\
\hline $\begin{array}{l}\text { Non- } \\
\text { migrant }\end{array}$ & $\begin{array}{l}31.1 \\
(32)\end{array}$ & $\begin{array}{l}35.6 \\
(53)\end{array}$ & $\begin{array}{l}33.7 \\
(85)\end{array}$ & $\begin{array}{l}40.7 \\
(33)\end{array}$ & $\begin{array}{l}37.7 \\
(20)\end{array}$ & $\begin{array}{l}39.6 \\
(53)\end{array}$ \\
\hline Total & $\begin{array}{r}100.0 \% \\
41.0 \% \\
(103) \\
56.0 \%\end{array}$ & $\begin{array}{c}100.0 \% \\
59.0 \% \\
(149) \\
73.8 \%\end{array}$ & $\begin{array}{r}100.0 \% \\
100.0 \% \\
(252) \\
65.3 \%\end{array}$ & $\begin{array}{c}100.0 \% \\
60.0 \% \\
(81) \\
44.0 \%\end{array}$ & $\begin{array}{c}100.0 \% \\
40.0 \% \\
(53) \\
26.2 \%\end{array}$ & $\begin{array}{r}100.0 \% \\
100.0 \% \\
(134) \\
34.7 \%\end{array}$ \\
\hline
\end{tabular}

\begin{tabular}{|c|c|c|c|}
\hline For total & 1. 35181 & d.f. & .05908 \\
\hline mong males: & juare & $f .=2$ & $C=.10$ \\
\hline$\overline{\text { Among females: }}$ & Chi-square & d.f. $=2$ & $C=.04240$ \\
\hline
\end{tabular}

In terms of marital status, contrary to the findings of other studies (cf. Lee, 1966: 57; George, 1970: 188), the data of this research show that among migrant males, a greater proportion is single rather than married; the difference is even more striking among the young men who have returned to their original place of residence. The non-migrant males, on the other hand, are married in greater proportions rather than being single. In the total sample, 46 per cent of the males are married; 54 per cent are single. Females in all three categories of migrant, return migrant, and non-migrant are married rather than single. The high percentage of married female return migrants is noteworthy since it reverses the pattern found among males: 68 per cent of the female return migrants have married, whereas 70 per cent of the male return migrants are single. In the total sample, in contrast to the male sub-population, of the females, 62 per cent are married, 38 per cent are single. These data raise an important issue for interpretation: namely, whether geographical mobility limits marriage opportunities among males, or whether marriage limits geographical mobility. And how does one account for the patterns among females? The data indicate that single young persons, both males and females, but especially males, tend to be still migrants and return migrants, rather than non-migrants. These findings certainly suggest that marital status should be controlled in anlaysing the relationship between educational and career plans and migration. Since a very high proportion of the married respondents who are non-migrants or who have returned to their original place of residence have married persons born in the same county of Nova Scotia, these respondents are apparently pursuing their careers and building their married life in their community of origin. 
These trends are especially striking among the young women; all the married females who have returned to their community of origin have married Nova Scotians ( 89 per cent have married a man born in the woman's community of origin). The data certainly suggest that these women returned home "to settle down" - after going away for school, or for whatever other reason. Table 6 presents the distribution of migrants, return migrants, and non-migrants by birthplace of spouse and by sex.

TABLE 5. MARITAL STATUS OF RESPONDENTS BY MIGRANT STATUS

\begin{tabular}{|c|c|c|c|c|c|c|c|c|c|}
\hline \multirow{3}{*}{$\begin{array}{l}\text { Migrant } \\
\text { status }\end{array}$} & \multicolumn{9}{|c|}{ Marital status } \\
\hline & \multicolumn{3}{|c|}{ Single } & \multicolumn{3}{|c|}{ Now married } & \multicolumn{3}{|c|}{ Other } \\
\hline & $M$ & F & $\mathrm{T}$ & M & F & $\mathrm{T}$ & M & F & $\mathrm{T}$ \\
\hline $\begin{array}{l}\text { Migrant } \\
\text { Row \% }\end{array}$ & $\begin{array}{l}47.5 \% \\
(47) \\
56.0 \%\end{array}$ & $\begin{array}{l}44.7 \% \\
(34) \\
38.2 \%\end{array}$ & $\begin{array}{l}46.3 \% \\
(81) \\
46.8 \%\end{array}$ & $\begin{array}{l}45.7 \% \\
(37) \\
44.0 \%\end{array}$ & $\begin{array}{l}42.5 \% \\
(51) \\
57.3 \%\end{array}$ & $\begin{array}{l}43.8 \% \\
(88) \\
50.9 \%\end{array}$ & & $\begin{array}{l}66.7 \% \\
(4) \\
4.4 \%\end{array}$ & $\begin{array}{l}50.0 \% \\
(4) \\
4.3 \%\end{array}$ \\
\hline $\begin{array}{l}\text { Return } \\
\text { migrant } \\
\quad \text { Row } \%\end{array}$ & $\begin{array}{l}23.2 \\
(23) \\
69.7 \%\end{array}$ & $\begin{array}{l}17.1 \\
(13) \\
32.5 \%\end{array}$ & $\begin{array}{l}20.6 \\
(36) \\
49.3 \%\end{array}$ & $\begin{array}{l}11.1 \\
(9) \\
27.3 \%\end{array}$ & $\begin{array}{l}21.7 \\
(26) \\
65.0 \%\end{array}$ & $\begin{array}{l}17.4 \\
(35) \\
48.0 \%\end{array}$ & $\begin{array}{l}50.0 \\
(1) \\
3.0 \%\end{array}$ & $\begin{array}{l}16.7 \\
(1) \\
2.5 \%\end{array}$ & $\begin{array}{l}25.0 \\
(2) \\
2.7 \%\end{array}$ \\
\hline $\begin{array}{r}\text { Non-migrant } \\
\text { Row } \%\end{array}$ & $\begin{array}{l}29.3 \\
(29) \\
44.6 \%\end{array}$ & $\begin{array}{l}38.2 \\
(29) \\
39.7 \%\end{array}$ & $\begin{array}{l}33.1 \\
(58) \\
42.0 \%\end{array}$ & $\begin{array}{l}43.2 \\
(35) \\
53.9 \%\end{array}$ & $\begin{array}{l}35.8 \\
(43) \\
58.9 \%\end{array}$ & $\begin{array}{l}38.8 \\
(78) \\
56.5 \%\end{array}$ & $\begin{array}{l}50.0 \\
(1) \\
1.5 \%\end{array}$ & $\begin{array}{l}16.7 \\
(1) \\
1.4 \%\end{array}$ & $\begin{array}{l}25.0 \\
(2) \\
1.5 \%\end{array}$ \\
\hline Total & $\begin{array}{c}100.0 \% \\
56.6 \% \\
(99) \\
54.4 \%\end{array}$ & $\begin{array}{c}100.0 \% \\
43.4 \% \\
(76) \\
37.6 \%\end{array}$ & $\begin{array}{c}100.0 \% \\
100.0 \% \\
(175) \\
45.6 \%\end{array}$ & $\begin{array}{c}100.0 \% \\
40.3 \% \\
(81) \\
44.5 \%\end{array}$ & $\begin{array}{c}100.0 \% \\
59.7 \% \\
(120) \\
59.4 \%\end{array}$ & $\begin{array}{l}100.0 \% \\
100.0 \% \\
(201) \\
52.3 \%\end{array}$ & $\begin{array}{c}100.0 \% \\
25.0 \% \\
(2) \\
1.1 \%\end{array}$ & $\begin{array}{c}100.0 \% \\
75.0 \% \\
(6) \\
3.0 \%\end{array}$ & $\begin{array}{c}100.0 \% \\
100.0 \% \\
(8) \\
2.1 \%\end{array}$ \\
\hline $\begin{array}{l}\text { For total samp] } \\
\text { Among males: } \\
\text { Among females: }\end{array}$ & $\begin{array}{l}\text { Chi } \\
\text { Chi } \\
\text { Chi }\end{array}$ & $\begin{array}{l}\text {-square } \\
\text {-square } \\
\text {-square }\end{array}$ & $\begin{array}{l}=1.9265 \\
=8.2385 \\
=2.0081\end{array}$ & & $\begin{array}{l}\text { f. }=4 \\
\text { f. }=4 \\
\text { f. }=4\end{array}$ & $\begin{array}{l}C= \\
C= \\
C=\end{array}$ & $\begin{array}{l}.07065 \\
.20810 \\
.09921\end{array}$ & & \\
\hline
\end{tabular}

TABLE 6. PERCENTAGE DISTRIBUTION OF MIGRANTS, RETURN MIGRANTS, BY BIRTHPLACE OF SPOUSE, BY SEX

\begin{tabular}{|c|c|c|c|c|c|c|c|c|c|c|}
\hline \multirow{3}{*}{$\begin{array}{l}\text { Birthplace } \\
\text { of spouse }\end{array}$} & \multicolumn{9}{|c|}{ Migrant status } & \multirow{3}{*}{ Total } \\
\hline & \multicolumn{3}{|c|}{ Migrants } & \multicolumn{3}{|c|}{ Return migrants } & \multicolumn{3}{|c|}{ Non-migrants } & \\
\hline & $\mathrm{M}$ & $F$ & $\mathrm{~T}$ & $\mathrm{M}$ & $F$ & $\mathrm{~T}$ & M & F & $T$ & \\
\hline $\begin{array}{l}\text { Same county } \\
\text { Nova Scotia }\end{array}$ & $\begin{array}{r}22.3 \% \\
(8)\end{array}$ & $\begin{array}{c}27.8 \% \\
(15)\end{array}$ & $\begin{array}{r}25.5 \% \\
(23)\end{array}$ & $\begin{array}{l}80.0 \% \\
(8)\end{array}$ & $\begin{array}{c}88.9 \% \\
(24)\end{array}$ & $\begin{array}{c}86.4 \% \\
(32)\end{array}$ & $\begin{array}{r}77.0 \% \\
(27)\end{array}$ & $\begin{array}{c}84.4 \% \\
(38)\end{array}$ & $\begin{array}{c}81.3 \% \\
(65)\end{array}$ & $\begin{array}{l}58.0 \% \\
(120)\end{array}$ \\
\hline $\begin{array}{l}\text { Other county } \\
\text { Nova Scotia }\end{array}$ & $\begin{array}{c}22.3 \% \\
\quad(8)\end{array}$ & $\begin{array}{c}33.3 \% \\
(18)\end{array}$ & $\begin{array}{c}28.9 \% \\
(26)\end{array}$ & & $\begin{array}{l}12.1 \% \\
\text { (3) }\end{array}$ & $\begin{array}{l}8.1 \% \\
(3)\end{array}$ & $\begin{array}{r}14.3 \% \\
(5)\end{array}$ & $\begin{array}{r}6.8 \% \\
(3)\end{array}$ & $\begin{array}{r}10.0 \% \\
(8)\end{array}$ & $\begin{array}{r}17.9 \% \\
(37)\end{array}$ \\
\hline $\begin{array}{l}\text { Other } \\
\text { Atlantic }\end{array}$ & $\begin{array}{c}16.6 \% \\
(6)\end{array}$ & $\begin{array}{c}7.4 \% \\
(4)\end{array}$ & $\begin{array}{c}11.1 \% \\
(10)\end{array}$ & $\begin{array}{r}20.0 \% \\
(2)\end{array}$ & & $\begin{array}{r}5.5 \% \\
(2)\end{array}$ & & & & $\begin{array}{l}5.8 \% \\
(12)\end{array}$ \\
\hline $\begin{array}{l}\text { Elsewhere } \\
\text { Canada }\end{array}$ & $\begin{array}{c}30.5 \% \\
\text { (11) }\end{array}$ & $\begin{array}{l}20.4 \% \\
\text { (11) }\end{array}$ & $\begin{array}{c}24.4 \% \\
(22)\end{array}$ & & & & $\begin{array}{r}5.8 \% \\
(2)\end{array}$ & $\begin{array}{r}4.4 \% \\
(2)\end{array}$ & $\begin{array}{c}5.0 \% \\
(4)\end{array}$ & $\begin{array}{r}12.5 \% \\
(26)\end{array}$ \\
\hline Outside & $\begin{array}{l}8.3 \% \\
(3)\end{array}$ & $\begin{array}{r}11.1 \% \\
(6)\end{array}$ & $\begin{array}{r}10.1 \% \\
(9)\end{array}$ & & & & $\begin{array}{r}2.9 \% \\
(1)\end{array}$ & $\begin{array}{r}4.4 \% \\
(2)\end{array}$ & $\begin{array}{l}3.7 \% \\
(3)\end{array}$ & $\begin{array}{l}5.8 \% \\
(12)\end{array}$ \\
\hline Total & $\begin{array}{c}100.0 \% \\
(36)\end{array}$ & $\begin{array}{c}100.0 \% \\
(54)\end{array}$ & $\begin{array}{c}100.0 \% \\
(90)\end{array}$ & $\begin{array}{c}100.0 \% \\
(10)\end{array}$ & $\begin{array}{c}100.0 \% \\
(27)\end{array}$ & $\begin{array}{c}100.0 \% \\
(37)\end{array}$ & $\begin{array}{c}100.0 \% \\
(35)\end{array}$ & $\begin{array}{c}100.0 \% \\
(45)\end{array}$ & $\begin{array}{c}100.0 \% \\
(80)\end{array}$ & $\begin{array}{r}100.0 \% \\
(207)\end{array}$ \\
\hline
\end{tabular}


Helen Ralston

As compared to the Nova Scotia population in the 20-24 age-category, both males and females in the sample have married in greater proportions. In Table 7 the sample is compared with the Nova Scotia population aged 20-29 years in terms of their marital status. The findings are contrary to what might be expected of this sample. It is a sample of relatively well-educated respondents. One would assume that the level of education of the sample would be higher than that of the total Nova Scotia population of the same age cohort; and it would seem reasonable to hypothesize that the better educated would marry at a slightly older age than the less well educated. Yet the data seem to suggest the opposite. Some clarification of this apparent paradox is provided by further analysis of the data in terms of education attainment at the post-secondary level. Analysis of the marital status of the college-educated respondents (as distinct from those who had any kind of post-secondary education) reveals that there is a greater proportion of unmarried college-educated males and females than in the sample as a whole, and than in the Nova Scotia population in the same age-cohorts; the differences are most marked among males in the younger 20-24 age-category, but they are also strong among females in the 20-24 age-category. These data suggest that the more highly educated are the most geographically mobile respondents, and that they tend to marry at a later age.

The main explanatory variables used to test the general hypothesis of the present study are the educational plans expressed by the respondents as high school students in 1965 and the congruence (or consistency) between their plans for continuing education in 1965 and subsequent educational attainment in 1972. These variables are each correlated with their migrant status in 1972. The longitudinal data are presented in Tables 8 and 9, respectively. One hypothesis proposing that those who aspire to post-secondary education are more likely to migrate than those who do not aspire to post-secondary education is confirmed among males but not among females. The second hypothesis proposes that migrant status is directly associated with congruence between aspirations to post-secondary education and actual attainment of some post-secondary education. This hypothesis is not confirmed. The data for attainment of postsecondary education include, however, those respondents who have any post-secondary education, whether it is for only one year or for more than one year, and whether it is at university or at some non-university post-secondary institution. Of the ninety four respondents (sixty seven, or 71 per cent males; twenty seven or 29 per cent females) who have continued their education at university, 63 per cent of the males as compared to 52 per cent of the females are migrants, albeit within the province of Nova Scotia or the Atlantic region. These data confirm that a relatively high percentage of the best educated males tend to migrate. This conclusion is supported by analysis of the relationship between continuation of education at the postsecondary level and migrant status. The findings presented in Table 10 show that continuation of education at the post-secondary level is significantly related to migration. When sex is controlled, the relationship holds more firmly for males than for females. In other words, migration-selects-the-better-edueated,particularly-the-better-edueated-males.

In general, males have continued their education at the post-secondary level in greater proportions than females ( 73 per cent of the males, as compared to 65 per cent of the females). The mean number of years of post-secondary schooling is also higher for males than for females (2.4 years as compared to 1.9 years). Perhaps one of the most striking findings with respect to sex differences, however, is in the data regarding the kind of post-secondary school attended by males and females. Here the normative sex-patterns for post-secondary education in our culture are clearly evident. There is virtually no overlap between the two sexes, as the data presented in Table 11 clearly show. Whereas 50 per cent of the males attended college or university, only 20 per cent of the females did so. Among the non-university institutions attended by females, business college accounts for 38 per cent of the females; nursing school, 14 per cent; teacher's college, 6 per cent. For males, on the other hand, an institute of technology accounts for 24 per cent. 
Education and Migration Among Nova Scotia Youth

TABLE 7. MARITAL STATUS OF NOVA SCOTIA POPULATION, 1972 RESEARCH SAMPLE, AND COLLEGE-EDUCATED RESPONDENTS BY AGE-GROUP AND SEX

\begin{tabular}{|c|c|c|c|c|c|c|c|}
\hline \multirow{3}{*}{$\begin{array}{l}\text { Marital } \\
\text { status }\end{array}$} & \multicolumn{6}{|c|}{ Age-group } & \multirow{3}{*}{ Total } \\
\hline & \multicolumn{3}{|c|}{$20-24$ years } & \multicolumn{3}{|c|}{$25-29$ years } & \\
\hline & M & F & Total & M & $\mathrm{F}$ & Total & \\
\hline \multicolumn{8}{|l|}{ Nova Scotia ${ }^{a}$} \\
\hline Single & $\begin{array}{l}64.7 \% \\
(22.4)\end{array}$ & $\begin{array}{l}41.6 \% \\
(14.1)\end{array}$ & $\begin{array}{l}53.3 \% \\
(36.5)\end{array}$ & $\begin{array}{r}23.7 \% \\
(6.3)\end{array}$ & $\begin{array}{r}13.1 \% \\
(3.3)\end{array}$ & $\begin{array}{c}18.2 \% \\
(9.7)\end{array}$ & $\begin{array}{l}38.2 \% \\
(46.2)\end{array}$ \\
\hline Married ${ }^{b}$ & $\begin{array}{l}35.0 \% \\
(12.1)\end{array}$ & $\begin{array}{l}57.6 \% \\
(19.4)\end{array}$ & $\begin{array}{c}46.1 \% \\
(31.6)\end{array}$ & $\begin{array}{l}75.2 \% \\
(20.1)\end{array}$ & $\begin{array}{l}85.0 \% \\
(21.8)\end{array}$ & $\begin{array}{l}80.3 \% \\
(41.9)\end{array}$ & $\begin{array}{l}60.8 \% \\
(73.5)\end{array}$ \\
\hline Other & $\begin{array}{r}0.3 \% \\
(0.1) \\
\end{array}$ & $\begin{array}{c}0.8 \% \\
(0.3) \\
\end{array}$ & $\begin{array}{r}0.6 \% \\
(0.4) \\
\end{array}$ & $\begin{array}{r}1.1 \% \\
(0.3) \\
\end{array}$ & $\begin{array}{r}1.9 \% \\
(0.5) \\
\end{array}$ & $\begin{array}{r}1.5 \% \\
(0.8) \\
\end{array}$ & $\begin{array}{r}1.0 \% \\
(1.2) \\
\end{array}$ \\
\hline Total & $\begin{array}{l}100.0 \% \\
(34.6)\end{array}$ & $\begin{array}{l}100.0 \% \\
(33.8)\end{array}$ & $\begin{array}{l}100.0 \% \\
(68.5)\end{array}$ & $\begin{array}{l}100.0 \% \\
(26.7)\end{array}$ & $\begin{array}{l}100.0 \% \\
(25.6)\end{array}$ & $\begin{array}{l}100.0 \% \\
(52.4)\end{array}$ & $\begin{array}{l}100.0 \% \\
(120.9)\end{array}$ \\
\hline \multicolumn{8}{|l|}{$\begin{array}{l}\text { Research } \\
\text { sample }\end{array}$} \\
\hline Single & $\begin{array}{l}59.9 \% \\
(85)\end{array}$ & $\begin{array}{l}38.7 \% \\
(70)\end{array}$ & $\begin{array}{l}48.0 \% \\
(155)\end{array}$ & $\begin{array}{l}35.9 \% \\
(14)\end{array}$ & $\begin{array}{c}21.1 \% \\
(4)\end{array}$ & $\begin{array}{l}31.0 \% \\
(18)\end{array}$ & $\begin{array}{l}45.4 \% \\
(173)\end{array}$ \\
\hline Married ${ }^{\mathrm{b}}$ & $\begin{array}{l}40.1 \% \\
(57)\end{array}$ & $\begin{array}{l}60.2 \% \\
(109)\end{array}$ & $\begin{array}{l}51.4 \% \\
(166)\end{array}$ & $\begin{array}{l}64.1 \% \\
(25)\end{array}$ & $\begin{array}{l}78.9 \% \\
(15)\end{array}$ & $\begin{array}{l}69.0 \% \\
(40)\end{array}$ & $\begin{array}{l}54.1 \% \\
(206)\end{array}$ \\
\hline Other & $\begin{array}{l}0.0 \% \\
(0)\end{array}$ & $\begin{array}{l}1.1 \% \\
(2)\end{array}$ & $\begin{array}{l}0.6 \% \\
(2) \\
\end{array}$ & $\begin{array}{l}0.0 \% \\
(0)\end{array}$ & $\begin{array}{l}0.0 \% \\
(0)\end{array}$ & $\begin{array}{l}0.0 \% \\
(0)\end{array}$ & $\begin{array}{l}0.5 \% \\
(2)\end{array}$ \\
\hline Total & $\begin{array}{l}100.0 \% \\
(142)\end{array}$ & $\begin{array}{l}100.0 \% \\
(182)\end{array}$ & $\begin{array}{l}100.0 \% \\
(323)\end{array}$ & $\begin{array}{c}100.0 \% \\
(39)\end{array}$ & $\begin{array}{c}100.0 \% \\
(19)\end{array}$ & $\begin{array}{c}100.0 \% \\
(58)\end{array}$ & $\begin{array}{l}100.0 \% \\
(381)\end{array}$ \\
\hline \multicolumn{8}{|l|}{$\begin{array}{l}\text { College- } \\
\text { educated }\end{array}$} \\
\hline Single & $\begin{array}{l}74.1 \% \\
(40)\end{array}$ & $\begin{array}{l}65.4 \% \\
(17)\end{array}$ & $\begin{array}{l}63.1 \% \\
(57)\end{array}$ & $\begin{array}{l}9.1 \% \\
(1)\end{array}$ & 0 & $\begin{array}{l}9.1 \% \\
(1)\end{array}$ & $\begin{array}{l}63.8 \% \\
(58)\end{array}$ \\
\hline $\begin{array}{l}\text { Married } \\
\text { Other }\end{array}$ & $\begin{array}{l}25.9 \% \\
(14)\end{array}$ & $\begin{array}{c}34.6 \% \\
(9)\end{array}$ & $\begin{array}{l}36.9 \% \\
(23)\end{array}$ & $\begin{array}{l}90.9 \% \\
(10)\end{array}$ & 0 & $\begin{array}{l}90.0 \% \\
(10)\end{array}$ & $\begin{array}{l}36.2 \% \\
(33)\end{array}$ \\
\hline Total & $\begin{array}{c}100.0 \% \\
(54)\end{array}$ & $\begin{array}{c}100.0 \% \\
(26)\end{array}$ & $\begin{array}{c}100.0 \% \\
(80)\end{array}$ & $\begin{array}{c}100.0 \% \\
(11)\end{array}$ & 0 & $\begin{array}{c}100.0 \% \\
\text { (11) }\end{array}$ & $\begin{array}{c}100.0 \% \\
(91)\end{array}$ \\
\hline
\end{tabular}

Nova Scotia population in thousands, 1971 Census of Canada, $\$ 92-730$, Marital Status by Age Groups; Table 2: 2-1

$b_{\text {Includes separated }}$ 
Helen Ralston

TABLE 8. MIGRANT STATUS IN 1972 BY POST-SECONDARY EDUCATIONAL ASPIRATIONS IN 1965, SEX CONTROLLED

\begin{tabular}{l|c|c|c|c|c|c}
\hline \multirow{2}{*}{$\begin{array}{l}\text { Migrant } \\
\text { status }\end{array}$} & \multicolumn{6}{|c|}{ Aspirations to post-secondary education } \\
\cline { 2 - 7 } & \multicolumn{3}{|c|}{ Yes } & \multicolumn{3}{c}{ No } \\
\cline { 2 - 7 } & $\mathrm{M}$ & $\mathrm{F}$ & Total & $\mathrm{M}$ & $\mathrm{F}$ & Total \\
\hline \multirow{2}{*}{ Migrant } & $\begin{array}{l}71.6 \% \\
(78)\end{array}$ & $\begin{array}{l}62.2 \% \\
(79)\end{array}$ & $\begin{array}{l}66.5 \% \\
(157)\end{array}$ & $\begin{array}{l}54.7 \% \\
(41)\end{array}$ & $\begin{array}{l}66.7 \% \\
(50)\end{array}$ & $\begin{array}{l}60.7 \% \\
(91)\end{array}$ \\
Non-migrant & $\begin{array}{l}28.4 \% \\
(31)\end{array}$ & $\begin{array}{l}37.8 \% \\
(48)\end{array}$ & $\begin{array}{l}33.5 \% \\
(79)\end{array}$ & $\begin{array}{l}45.3 \% \\
(34)\end{array}$ & $\begin{array}{l}33.3 \% \\
(25)\end{array}$ & $\begin{array}{l}39.3 \% \\
(59)\end{array}$ \\
\hline Tota1 & $100.0 \%$ & $100.0 \%$ & $100.0 \%$ & $\begin{array}{l}100.0 \% \\
(75)\end{array}$ & $\begin{array}{c}100.0 \% \\
(75)\end{array}$ & $\begin{array}{l}100.0 \% \\
(150)\end{array}$ \\
\hline
\end{tabular}

For total sample: For males: For females:
Chi square $=1.12728$

Chi square $=4.83477 * *$

Chi square $=.23641$ d.f. $=1$

$\mathrm{C}=.05396$

d.f. $=1$

d.f. $=1$
$\mathrm{C}=.16001$

$\mathrm{C}=.03419$

TABLE 9. MIGRANT STATUS BY CONGRUENCE BETWEEN POST-SECONDARY EDUCATIONAL ASPIRATIONS AND POST-SECONDARY EDUCATIONAL ATTAINMENT, BY SEX

\begin{tabular}{|c|c|c|c|c|c|c|}
\hline & \multicolumn{6}{|c|}{$\begin{array}{c}\text { Relation between educational aspirations and } \\
\text { educational attainment }\end{array}$} \\
\hline & \multicolumn{3}{|c|}{ Congruent } & \multicolumn{3}{|c|}{ Incongruent } \\
\hline & Male & Female & Total & Male & Female & Total \\
\hline Migrant & $\begin{array}{l}68.8 \% \\
(77)\end{array}$ & $\begin{array}{l}65.2 \% \\
(88)\end{array}$ & $\begin{array}{l}66.8 \% \\
(165)\end{array}$ & $\begin{array}{l}57.7 \% \\
(41)\end{array}$ & $\begin{array}{l}61.2 \% \\
(41)\end{array}$ & $\begin{array}{l}59.4 \% \\
(82)\end{array}$ \\
\hline Non-migrant & $\begin{array}{l}31.3 \% \\
(35)\end{array}$ & $\begin{array}{l}34.8 \% \\
(47)\end{array}$ & $\begin{array}{l}33.2 \% \\
(82)\end{array}$ & $\begin{array}{l}42.3 \% \\
(30)\end{array}$ & $\begin{array}{l}38.8 \% \\
(26)\end{array}$ & $\begin{array}{l}40.6 \% \\
(56)\end{array}$ \\
\hline Total & $\begin{array}{l}100.0 \% \\
(112)\end{array}$ & $\begin{array}{l}100.0 \% \\
(135)\end{array}$ & $\begin{array}{l}100.0 \% \\
(247)\end{array}$ & $\begin{array}{c}100.0 \% \\
(71)\end{array}$ & $\begin{array}{l}100.0 \% \\
(67)\end{array}$ & $\begin{array}{l}100.0 \% \\
(138)\end{array}$ \\
\hline $\begin{array}{l}\text { For total sa } \\
\text { Among males } \\
\text { Among female }\end{array}$ & le: & $\begin{array}{l}\text { Chi squar } \\
\text { Chi squar } \\
\text { Chi squar }\end{array}$ & $\begin{array}{l}=1.7889 \\
=1.8418 \\
=.1603\end{array}$ & $\begin{array}{l}\text { d.f. } \\
\text { d.f. } \\
\text { d. f. }\end{array}$ & $\begin{array}{l}1 \\
1 \\
1\end{array}$ & $\begin{array}{l}.06801 \\
.09982 \\
.02816\end{array}$ \\
\hline
\end{tabular}


Education and Migration Among Nova Scotia Youth

TABLE 10. POST-SECONDARY EDUCATIONAL ATTAINMENT BY MIGRANT STATUS

\begin{tabular}{|c|c|c|c|c|c|c|}
\hline \multirow{3}{*}{$\begin{array}{l}\text { Migrant } \\
\text { Status }\end{array}$} & \multicolumn{6}{|c|}{ Attainment of post-secondary education } \\
\hline & \multicolumn{3}{|c|}{ Yes } & \multicolumn{3}{|c|}{ No } \\
\hline & $\mathrm{M}$ & F & $\mathrm{T}$ & $\mathrm{M}$ & $\mathrm{F}$ & $\mathrm{T}$ \\
\hline Migrant & $\begin{array}{l}50.7 \% \\
(68)\end{array}$ & $\begin{array}{l}48.5 \% \\
(64)\end{array}$ & $\begin{array}{l}49.6 \% \\
(132)\end{array}$ & $\begin{array}{l}36.0 \% \\
(18)\end{array}$ & $\begin{array}{l}35.7 \% \\
(25)\end{array}$ & $\begin{array}{l}35.8 \% \\
(43)\end{array}$ \\
\hline $\begin{array}{l}\text { Return } \\
\text { migrant }\end{array}$ & $\begin{array}{l}20.1 \\
(27)\end{array}$ & $\begin{array}{l}16.7 \\
(22)\end{array}$ & $\begin{array}{l}18.4 \\
(49)\end{array}$ & $\begin{array}{r}12.0 \\
(6)\end{array}$ & $\begin{array}{l}25.7 \\
(18)\end{array}$ & $\begin{array}{l}20.0 \\
(24)\end{array}$ \\
\hline $\begin{array}{l}\text { Non- } \\
\quad \text { migrant }\end{array}$ & $\begin{array}{l}29.1 \\
(39)\end{array}$ & $\begin{array}{l}34.8 \\
(46)\end{array}$ & $\begin{array}{l}32.0 \\
(85)\end{array}$ & $\begin{array}{l}52.0 \\
(26)\end{array}$ & $\begin{array}{l}38.6 \\
(27)\end{array}$ & $\begin{array}{l}44.2 \\
(53)\end{array}$ \\
\hline $\begin{array}{l}\text { Total } \\
\qquad \text { Row \% }\end{array}$ & $\begin{array}{r}100.0 \% \\
(134) \\
72.8 \%\end{array}$ & $\begin{array}{r}100.0 \% \\
(132) \\
65.3 \%\end{array}$ & $\begin{array}{c}100.0 \% \\
(266) \\
68.9 \%\end{array}$ & $\begin{array}{l}100.0 \% \\
(50) \\
27.2 \%\end{array}$ & $\begin{array}{l}100.0 \% \\
(70) \\
34.7 \%\end{array}$ & $\begin{array}{l}100.0 \% \\
(120) \\
31.1 \%\end{array}$ \\
\hline $\begin{array}{l}\text { For total sample: } \\
\text { Among males: } \\
\text { Among females: }\end{array}$ & $\begin{array}{l}\text { Chi-s } \\
\text { Chi-s } \\
\text { Chi-s }\end{array}$ & $\begin{array}{l}\text { dare }= \\
\text { dare }= \\
\text { dare }=\end{array}$ & $\begin{array}{l}02736 * * \\
44577 * * * \\
75957\end{array}$ & $\begin{array}{l}\text { d.f. }=2 \\
\text { d.f. }=2 \\
\text { d.f. }=2\end{array}$ & $\begin{array}{l}C=.13 \\
C=.20 \\
C=.13\end{array}$ & \\
\hline
\end{tabular}

How does the research sample compare with the same age-cohort of the Nova Scotia population with respect to post-secondary education? In Table 12, the findings among the research respondents have been compared with the data for full-time post-secondary enrolment, related to the relevant age-category, in the Province of Nova Scotia, for the year 1972-73. As might be expected, the respondents in the research sample are enrolled in post-secondary education in greater proportions than the 18-24 age-cohort of the Nova Scotia population; when selected for participation in the Career Decisions Project 1965, they were already high-school students. Like the respondents in the research sample, Nova Scotia females in 1972 are more highly represented than males in non-university post-secondary instutitions; females are less highly represented than males in universities, particularly at the graduate level. The most striking feature of the comparative data is that the sex differentials are much greater in the research sample than in the Nova Scotia population as a whole in terms of the kind of postsecondary institution attended. In the research sample, proportionately fewer females attended university and proportionately more attended other types of post-secondary institutions than in the relevant age-cohort of the Nova Scotia population as a whole. It is to be noted that females in the research sample, as compared to males, came from smaller communities in greater proportions, where universities are less likely to be located. Perhaps this objective factor influenced the kind of institution they attended, and their perceptions of the opportunity structure, and, in turn, their migratory patterns. Part of the migration selectivity observed among the better educated young people (particularly the better educated males) may in fact be migration to seek the post-secondary education available in large urban areas. 
Helen Ralston

TABLE 11. PERCENTAGE DISTRIBUTION OF RESPONDENTS WITH
POSTSECONDARY EDUCATION BY TYPE OF POST-SECONDARY
SCHOOL ATTENDED, BY SEX

\begin{tabular}{l|c|c|c|}
\hline \hline Type of post-secondary school & Males & Females & Total \\
\hline Business college & $1.5 \%$ & $\begin{array}{l}37.9 \% \\
(50)\end{array}$ & $\begin{array}{l}19.6 \% \\
(52)\end{array}$ \\
Agricul tural college or institute & $0.7 \%$ & $0.7 \%$ & $0.8 \%$ \\
& $(1)$ & $(1)$ & $(2)$ \\
Teacher's college or normal school & $0.7 \%$ & $\begin{array}{l}6.1 \% \\
(8)\end{array}$ & $3.4 \%$ \\
& $(1)$ & $(9)$ \\
Nursing school & & $14.4 \%$ & $7.1 \%$ \\
Theological school or seminary & $(19)$ & $(19)$ \\
Institute of technology or similar school & $23.9 \%$ & $4.5 \%$ & $14.3 \%$ \\
& $(32)$ & $(6)$ & $(38)$ \\
College or university & $50.0 \%$ & $20.5 \%$ & $35.3 \%$ \\
& $(67)$ & $(27)$ & $(94)$ \\
Other & $23.2 \%$ & $15.9 \%$ & $19.5 \%$ \\
& $(31)$ & $(21)$ & $(52)$ \\
\hline
\end{tabular}

Why have migrants moved? There are important sex differentials in the motives for migration. The data presented in Table 13 show that a high proportion of the respondents ( 29 per cent) have in fact moved to continue their education; a higher proportion of males than females ( 33 per cent and 25 per cent, respectively) have given continuation of education as the main reason for moving. These data clearly suggest that continuation of education is a powerful motivating factor for migration. Together with job-related reasons, it accounts for over twothirds of the migration among both categories of male migrants; and for 42 per cent of the migration of migrant females and 58 per cent of the migration among females who have returned to their 1965 community of residence. On the other hand, among all the young people who said that they moved to continue their education, the young women have been more apt to return than the young men. The data presented in Table 13 show that of the thirty nine males who went away to continue their education, twenty eight ( 72 per cent) are still migrants and eleven ( 28 per cent) have returned; of the thirty two females who went away to continue their education, only nineteen ( 59 per cent) are still migrants and thirteen ( 41 per cent) have returned. 
Education and Migration Among Nova Scotia Youth

TABLE 12. FULL-TIME POST-SECONDARY ENROLMENT, BY LEVEL, RELATED TO RELEVANT POPULATION, NOVA SCOTIA, 1972-73“

\begin{tabular}{|c|c|c|c|}
\hline Post-secondary enrolment & Males & Females & Total \\
\hline $\begin{array}{l}\frac{\text { Total }}{\text { Number }} \\
\text { Related }(\%) \\
\text { to age } 18-24\end{array}$ & $\begin{array}{l}10,501 \\
20.1 \%\end{array}$ & $\begin{array}{l}8,072 \\
16.0 \%\end{array}$ & $\begin{array}{r}18,573 \\
18.1 \%\end{array}$ \\
\hline $\begin{array}{l}\frac{\text { Non-university level }}{}^{\mathrm{b}} \\
\text { Number } \\
\text { Related }(\%) \\
\text { to age } 18-21\end{array}$ & $\begin{array}{r}816 \\
2.6 \%\end{array}$ & $\begin{array}{l}1,531 \\
5.1 \%\end{array}$ & $\begin{array}{l}2,347 \\
3.8 \%\end{array}$ \\
\hline University level & & & \\
\hline $\begin{array}{l}\text { Undergraduate } \\
\text { Number } \\
\text { Related }(\%) \\
\text { to age } 18-21\end{array}$ & $\begin{array}{l}8,831 \\
28.0 \%\end{array}$ & $\begin{array}{l}6,233 \\
20.6 \%\end{array}$ & $\begin{array}{l}15,064 \\
24.4 \%\end{array}$ \\
\hline $\begin{array}{l}\text { Graduate } \\
\text { Number } \\
\text { Related }(\%) \\
\text { to age } 22-24\end{array}$ & $\begin{array}{r}854 \\
14.1 \%\end{array}$ & $\begin{array}{r}308 \\
1.5 \%\end{array}$ & $\begin{array}{r}1,162 \\
2.8 \%\end{array}$ \\
\hline $\begin{array}{l}\text { Sub-total university } \\
\text { Number } \\
\text { Related }(\%) \\
\text { to age } 18-24\end{array}$ & $\begin{array}{l}9,685 \\
18.6 \%\end{array}$ & $\begin{array}{l}6,541 \\
13.0 \%\end{array}$ & $\begin{array}{r}16,226 \\
15.8 \%\end{array}$ \\
\hline
\end{tabular}

${ }^{a}$ Source Statistics Canada. Education in Canada: A Statistical Review for 1971-72 and 1972-73, 非1-229, Table 38, pp. 172-173. Distribution by sex provided by Regional office, Statistics Canada, Halifax.

${ }^{b}$ Includes students in post-secondary non-university level programmes, regardless of the type of institution in which they are enrolled. 
Helen Ralston

TABLE 13. DISTRIBUTION OF MIGRANTS, RETURN MIGRANTS, BY MOTIVE FOR MIGRATION

\begin{tabular}{|c|c|c|c|c|c|c|c|c|c|}
\hline \multirow{2}{*}{$\begin{array}{l}\text { Motive for } \\
\text { migration }\end{array}$} & \multicolumn{3}{|c|}{ Migrants } & \multicolumn{3}{|c|}{ Return migrants } & \multicolumn{3}{|c|}{ Total migrants } \\
\hline & $M$ & F & $T$ & M & $\mathrm{F}$ & $T$ & M & $\mathrm{F}$ & $\mathrm{T}$ \\
\hline $\begin{array}{l}\text { My parents moved and } \\
\text { I went with them }\end{array}$ & $\begin{array}{l}14.3 \% \\
(12)\end{array}$ & $\begin{array}{l}10.3 \% \\
(9)\end{array}$ & $\begin{array}{l}12.2 \% \\
(21)\end{array}$ & & $\begin{array}{l}2.5 \% \\
(1)\end{array}$ & $\begin{array}{l}1.4 \% \\
(1)\end{array}$ & $\begin{array}{l}10.3 \% \\
(12)\end{array}$ & $\begin{array}{l}7.9 \% \\
(10)\end{array}$ & $\begin{array}{l}9.0 \% \\
(22)\end{array}$ \\
\hline $\begin{array}{l}\text { To continue my } \\
\text { education }\end{array}$ & $\begin{array}{l}33.3 \% \\
(28)\end{array}$ & $\begin{array}{l}21.8 \% \\
(19)\end{array}$ & $\begin{array}{l}27.5 \% \\
(47)\end{array}$ & $\begin{array}{l}33.3 \% \\
\text { (11) }\end{array}$ & $\begin{array}{l}32.5 \% \\
(13)\end{array}$ & $\begin{array}{l}32.9 \% \\
(24)\end{array}$ & $\begin{array}{l}33.3 \% \\
(39)\end{array}$ & $\begin{array}{l}25.2 \% \\
(32)\end{array}$ & $\begin{array}{l}29.1 \% \\
(71)\end{array}$ \\
\hline $\begin{array}{l}\text { To take a temporary } \\
\text { job waiting for me }\end{array}$ & $\begin{array}{l}1.2 \% \\
(1)\end{array}$ & & $\stackrel{.6 \%}{(1)}$ & & $\begin{array}{l}2: 5 \% \\
(1)\end{array}$ & $\begin{array}{l}1.4 \% \\
(1)\end{array}$ & $\begin{array}{l}0.9 \% \\
(1)\end{array}$ & $\begin{array}{l}0.8 \% \\
\text { (1) }\end{array}$ & $\begin{array}{l}0.8 \% \\
(2)\end{array}$ \\
\hline $\begin{array}{l}\text { To take a steady job } \\
\text { waiting for me }\end{array}$ & $\begin{array}{l}22.6 \% \\
(19)\end{array}$ & $\begin{array}{l}10.3 \% \\
(9)\end{array}$ & $\begin{array}{l}16.3 \% \\
(28)\end{array}$ & $\begin{array}{l}15.2 \% \\
(5)\end{array}$ & $\begin{array}{c}10.0 \% \\
(4)\end{array}$ & $\begin{array}{l}12.3 \% \\
(9)\end{array}$ & $\begin{array}{l}20.5 \% \\
(24)\end{array}$ & $\begin{array}{l}10.3 \% \\
(13)\end{array}$ & $\begin{array}{l}15.2 \% \\
(37)\end{array}$ \\
\hline $\begin{array}{l}\text { To look for a job in } \\
\text { line with qualifi- } \\
\text { cations }\end{array}$ & $\begin{array}{l}2.4 \% \\
(2)\end{array}$ & $\begin{array}{l}8.0 \% \\
(7)\end{array}$ & $\begin{array}{l}5.3 \% \\
(9)\end{array}$ & $\begin{array}{l}9.1 \% \\
(3)\end{array}$ & $\begin{array}{l}5.0 \% \\
(2)\end{array}$ & $\begin{array}{l}6.8 \% \\
(5)\end{array}$ & $\begin{array}{l}4.3 \% \\
(5)\end{array}$ & $\begin{array}{l}7.1 \% \\
(9)\end{array}$ & $\begin{array}{l}5.7 \% \\
(14)\end{array}$ \\
\hline $\begin{array}{l}\text { To look for any kind } \\
\text { of job }\end{array}$ & $\begin{array}{l}8.3 \% \\
(7)\end{array}$ & $\begin{array}{l}2.3 \% \\
(2)\end{array}$ & $\begin{array}{l}5.3 \% \\
(9)\end{array}$ & $\begin{array}{l}9.1 \% \\
(3)\end{array}$ & $\begin{array}{l}7.5 \% \\
(3)\end{array}$ & $\begin{array}{l}8.2 \% \\
(6)\end{array}$ & $\begin{array}{l}8.5 \% \\
(10)\end{array}$ & $\begin{array}{l}3.9 \% \\
(5)\end{array}$ & $\begin{array}{l}6.2 \% \\
(15)\end{array}$ \\
\hline $\begin{array}{l}\text { To be independent of } \\
\text { my family }\end{array}$ & $\begin{array}{l}1.2 \% \\
(1)\end{array}$ & &.$_{(1)}^{.6 \%}$ & $\begin{array}{l}3.0 \% \\
(1)\end{array}$ & $\begin{array}{l}2.5 \% \\
\text { (1) }\end{array}$ & $\begin{array}{l}2.7 \% \\
(2)\end{array}$ & $\begin{array}{l}1.7 \% \\
(2)\end{array}$ & $\begin{array}{l}0.8 \% \\
(1)\end{array}$ & $\begin{array}{l}1.2 \% \\
(3)\end{array}$ \\
\hline $\begin{array}{l}\text { To be with a boy } \\
\text { friend who went to } \\
\text { study elsewhere }\end{array}$ & & $\begin{array}{l}1.2 \% \\
(1)\end{array}$ &.$_{(1)}^{.6 \%}$ & & & & & $\begin{array}{l}0.8 \% \\
(1)\end{array}$ & $\begin{array}{l}0.4 \% \\
(1)\end{array}$ \\
\hline $\begin{array}{l}\text { To be with a boy } \\
\text { friend who went to } \\
\text { work elsewhere }\end{array}$ & & $\begin{array}{l}1.2 \% \\
(1)\end{array}$ & $(1) .6 \%$ & & & & & $\begin{array}{l}0.8 \% \\
(1)\end{array}$ & $\begin{array}{l}0.4 \% \\
(1)\end{array}$ \\
\hline To get married & & $\begin{array}{l}5.7 \% \\
(5)\end{array}$ & $\begin{array}{l}2.9 \% \\
(5)\end{array}$ & & & & & $\begin{array}{l}3.9 \% \\
(5)\end{array}$ & $\begin{array}{l}2.1 \% \\
(5)\end{array}$ \\
\hline $\begin{array}{l}\text { To be with my hus- } \\
\text { band who went to } \\
\text { study elsewhere }\end{array}$ & & $\begin{array}{l}1.2 \% \\
(1)\end{array}$ & 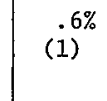 & & & & & $\begin{array}{l}0.8 \% \\
(1)\end{array}$ & $\begin{array}{l}0.4 \% \\
(1)\end{array}$ \\
\hline $\begin{array}{l}\text { To be with my hus- } \\
\text { band who went to } \\
\text { work elsewhere }\end{array}$ & & $\begin{array}{l}20.7 \% \\
(18)\end{array}$ & $\begin{array}{l}10.5 \% \\
(18)\end{array}$ & & $\begin{array}{c}12.5 \% \\
(5)\end{array}$ & $\begin{array}{l}6.8^{\%} \\
(5)\end{array}$ & & $\begin{array}{l}18.1 \% \\
(23)\end{array}$ & $\begin{array}{l}9.4 \% \\
(23)\end{array}$ \\
\hline To make more money & $\begin{array}{l}2.4 \% \\
(2) \\
\end{array}$ & & $\begin{array}{l}1.2 \% \\
(2)\end{array}$ & $\begin{array}{l}3.0 \% \\
(1)\end{array}$ & $\begin{array}{l}2.5 \% \\
(1)\end{array}$ & $\begin{array}{l}2.7 \% \\
(2)\end{array}$ & $\begin{array}{l}2.6 \% \\
(3)\end{array}$ & $\begin{array}{l}0.8 \% \\
(1)\end{array}$ & $\begin{array}{l}1.6 \% \\
(4)\end{array}$ \\
\hline I wanted to travel & $\begin{array}{l}3.6 \% \\
(3)\end{array}$ & $\begin{array}{l}1.2 \% \\
(1)\end{array}$ & $\begin{array}{l}2.3 \% \\
(4)\end{array}$ & $\begin{array}{l}9.1 \% \\
(3)\end{array}$ & $\begin{array}{l}7.5 \% \\
(3)\end{array}$ & $\begin{array}{l}8.2 \% \\
(6)\end{array}$ & $\begin{array}{l}5.1 \% \\
(6)\end{array}$ & $\begin{array}{l}3.1 \% \\
(4)\end{array}$ & $\begin{array}{l}4.1 \% \\
(10)\end{array}$ \\
\hline To get ahead in life & $\begin{array}{l}1.2 \% \\
(1)\end{array}$ & $\begin{array}{l}1.2 \% \\
(1)\end{array}$ & $\begin{array}{l}1.2 \% \\
(2)\end{array}$ & & & & $\begin{array}{l}0.9 \% \\
(1)\end{array}$ & $\begin{array}{l}0.8 \% \\
(1)\end{array}$ & $\begin{array}{l}0.8 \% \\
(2)\end{array}$ \\
\hline I wanted a change & $\begin{array}{l}3.6 \% \\
(3)\end{array}$ & $\begin{array}{l}12.6 \% \\
\text { (11) }\end{array}$ & $\begin{array}{l}8.2 \% \\
(14)\end{array}$ & & $\begin{array}{c}10.0 \% \\
(4)\end{array}$ & $\begin{array}{l}5.5 \% \\
(4)\end{array}$ & $\begin{array}{l}2.5 \% \\
(3)\end{array}$ & $\begin{array}{l}11.8 \% \\
(15)\end{array}$ & $\begin{array}{l}7.4 \% \\
(18)\end{array}$ \\
\hline Other (What? & $\begin{array}{l}5.9 \% \\
(5)\end{array}$ & $\begin{array}{l}2.3 \% \\
(2)\end{array}$ & $\begin{array}{l}4.1 \% \\
(7)\end{array}$ & $\begin{array}{c}18.2 \% \\
(5)\end{array}$ & $\begin{array}{l}5.0 \% \\
(2)\end{array}$ & $\begin{array}{c}11.1 \% \\
(8)\end{array}$ & $\begin{array}{l}9.4 \% \\
\text { (1i) } \\
\end{array}$ & $\begin{array}{l}3.1 \% \\
(4) \\
\end{array}$ & $\begin{array}{l}6.2 \% \\
(15) \\
\end{array}$ \\
\hline Total & $\begin{array}{c}100.0 \% \\
(84)\end{array}$ & $\begin{array}{c}100.0 \% \\
(87)\end{array}$ & $\begin{array}{c}100.0 \% \\
(171)\end{array}$ & $\begin{array}{c}100.0 \% \\
(33)\end{array}$ & $\begin{array}{c}100.0 \% \\
(40)\end{array}$ & $\begin{array}{c}100.0 \% \\
(73)\end{array}$ & $\begin{array}{r}100.0 \% \\
(117)\end{array}$ & $\begin{array}{c}100.0 \% \\
(127)\end{array}$ & $\begin{array}{r}100.0 \% \\
(244)\end{array}$ \\
\hline
\end{tabular}


Further analysis of the data reveals that of the thirteen women who went away from their 1965 residence to continue their education and subsequently returned to the same place, seven trained in nursing and para-medical professions (such as medical records, X-ray technician), four in teaching, one in business principles, and only one went to university; all continued their education within the province except one metropolitan Halifax woman who went out of the province to do nursing. Of these thirteen women who have returned to their original community of residence, ten are married, and all have married someone from their original residence; 33 per cent returned specifically to get married or because of their husband's job; the remainder returned for family ( 24 per cent) and community (24 per cent) reasons, with only two women returning for jobs associated with bursaries awarded for their post-secondary training. In contrast, of the eleven men who went away from their 1965 residence to continue their education and subsequently returned to the same place, six went to university within the province, four went to institutes of agriculture or technology, and one trained as an apprentice carpenter; seven of these young men returned for job reasons, two for family reasons, and two gave no reason for returning; only one young man went out of the province, and like the female inter-provincial return migrant who went away for educational reasons, he was a metropolitan Halifax resident. These results with respect to young people who went away to continue their education indicate that not only are young women more apt to return than young men, but that they are apt to return for different reasons, namely, to get married and settle down, rather than for job reasons. Although the motives expressed by the respondents as their main reason for moving cannot be equated with causes of migration (cf. Hawley, 1950: 328; DeJong and Ahmad, 1976: 268), they are an indicator of at least some of the motivation 'push' and 'pull' factors that enter into the migration decision.

The results of the investigation with respect to motives for migration suggest not only that perceptions of the opportunity structure differ for males and females, but also that objectively girls move to continue their education in different kinds of institutions from those that boys attend. This observation is particularly evident among those respondents who went away to continue their education and are still migrants: of the young men, 81 per cent went to university; of the young women, only 32 per cent went to university, and the majority of the others went to post-secondary institutions for nursing, para-medical, and secretarial occupations. Moreover, the young women have tended to migrate shorter distances than the young men. It is evident, however, that significant numbers of respondents, particularly females, have continued their education without migrating. Analysis of the data reveals that 60 per cent of the females (as compared to 42 per cent of the males) have continued their education in their community of origin (Table 14). Furthermore, over 90 per cent of the females have continued their education in the province of Nova Scotia. It is males who have gone in significant numbers to other provinces (especially Ontario) for post-secondary education. Nova Scotia has a large number of post-secondary institutions, including seven chartered universities, scattered throughout the province. In particular there are nursing schools, business and commercial schools, a teacher's college, in the large centres (Halifax, Sydney, New Glasgow, Truro, Yarmouth, Antigonish) traditionally the female post-secondary institutions. Males who migrated out of the province (to Ontario, for example) tended to enter universities or technical colleges, such as Ryerson. To a certain extent, therefore, the evidence suggests that for the female adolescent finishing high school, the opportunities are available within the province for post-secondary training to enter the woman's occupational world; she is less likely to consider non-traditional women's occupations, and she is less likely to have role models for these occupations; she is also less likely to migrate a great distance for her post-secondary training. Two cases illustrate this point quite well. A young woman told me that she migrated to a metropolitan centre to train as a lab technician; she had not thought of this as a career alternative to nursing until she met by chance a woman lab technician. Another woman studied to be a computer scientist; she had originally migrated out of the province to study near her boy friend. 
Helen Ralston

TABLE 14. PERCENTAGE DISTRIBUTION OF RESPONDENTS WITH POST-SECONDARY EDUCATION BY LOCATION OF POST-SECONDARY SCHOOL ATTENDED, BY SEX

\begin{tabular}{|c|c|c|c|}
\hline Location of post-secondary school & Males & Females & Total \\
\hline Same county, N.S. & $\begin{array}{r}41.8 \% \\
(56)\end{array}$ & $\begin{array}{c}60.3 \% \\
(79)\end{array}$ & $\begin{array}{l}50.9 \% \\
(135)\end{array}$ \\
\hline other county, N.S. & $\begin{aligned} 35.9 \% \\
(48)\end{aligned}$ & $\begin{array}{r}30.5 \% \\
(40)\end{array}$ & $\begin{array}{r}33.2 \% \\
(88)\end{array}$ \\
\hline Nf1d. & $\begin{array}{c}0.7 \% \\
(1)\end{array}$ & $\begin{array}{l}0.8 \% \\
(1)\end{array}$ & $\begin{array}{c}0.8 \% \\
(2)\end{array}$ \\
\hline N. B. & $\begin{array}{l}3.0 \% \\
(4)\end{array}$ & $\begin{array}{r}1.5 \% \\
(2)\end{array}$ & $\begin{array}{r}2.2 \% \\
(6)\end{array}$ \\
\hline P. E. I. & & $\begin{array}{r}0.8 \% \\
(1)\end{array}$ & $\begin{array}{r}0.4 \% \\
(1)\end{array}$ \\
\hline Que. & & & \\
\hline Ont. & $\begin{array}{c}13.4 \% \\
(18)\end{array}$ & $\begin{array}{c}3.8 \% \\
(5)\end{array}$ & $\begin{array}{l}8.7 \% \\
(23)\end{array}$ \\
\hline Man. & $\begin{array}{r}0.7 \% \\
(1)\end{array}$ & & $\begin{array}{c}0.4 \% \\
(1)\end{array}$ \\
\hline Sask. & & & \\
\hline Alta. & $\begin{array}{r}1.5 \% \\
(2)\end{array}$ & & $\begin{array}{r}0.8 \% \\
(2)\end{array}$ \\
\hline$-B \cdot-C$ & $1.5 \%$ & $1.5 \%$ & $1.5 \%$ \\
\hline Outside Ganada (U. S. A.) & $\begin{array}{l}1.5 \% \\
(2)\end{array}$ & $\begin{array}{r}0.8 \% \\
(1)\end{array}$ & $\begin{array}{r}1.1 \% \\
(3)\end{array}$ \\
\hline TOTAL & $\begin{array}{c}100.0 \% \\
(134)\end{array}$ & $\begin{array}{r}100.0 \% \\
(131)\end{array}$ & $\begin{array}{c}100.0 \% \\
(265)\end{array}$ \\
\hline
\end{tabular}


Three sub-hypotheses of the research propose relationships between social background variables and migration. The three variables, socio-economic status of the young person's family, family size, and family migratory history, respectively, are all directly associated with migration. ${ }^{3}$ These data (presented in Table 15 and 16) support the findings of other studies that migration is selective of persons of relatively high socio-economic status origin, from large families, and with migratory relatives (cf. Beijer, 1961; Blau and Duncan, 1967; Tilly and Brown, 1967; Marchwardt, 1968; Pike, 1970; Lucas, 1971; Elizaga, 1972; DeJong and Ahmad, 1976). In terms of sex differences, it is above all among males that the relationship between socio-economic status origin and migration is confirmed. Sixty-eight per cent of the males of high socio-economic status origin are still migrants. Socio-economic status origin is less significant for migration among females. Approximately half the females of both high and medium socio-economic status origins are still migrants. In general, in the sample as a whole, a greater proportion of females than males comes from a low socio-economic background ( 47 per cent of the females, as compared to 35 per cent of the males); whereas approximately 20 per cent of both males and females are of high socio-economic background.

TABLE 15. MIGRANT STATUS BY SOCIO-ECONOMIC STATUS ORIGIN, BY SEX

\begin{tabular}{|c|c|c|c|c|c|c|c|c|c|}
\hline \multirow{3}{*}{$\begin{array}{l}\text { Migrant } \\
\text { Status }\end{array}$} & \multicolumn{9}{|c|}{ Socio-economic status origin } \\
\hline & \multicolumn{3}{|c|}{ High } & \multicolumn{3}{|c|}{ Medium } & \multicolumn{3}{|c|}{ Low } \\
\hline & M & $F$ & $\mathrm{~T}$ & $M$ & $\mathrm{~F}$ & $\mathrm{~T}$ & $\mathrm{M}$ & $\mathrm{F}$ & $\mathrm{T}$ \\
\hline Migrant & $\begin{array}{l}67.6 \% \\
(23)\end{array}$ & $\begin{array}{l}50.0 \% \\
(18)\end{array}$ & $\begin{array}{l}58.6 \% \\
(41)\end{array}$ & $\begin{array}{l}44.8 \% \\
(30)\end{array}$ & $\begin{array}{l}51.6 \% \\
(31)\end{array}$ & $\begin{array}{l}48.0 \% \\
(61)\end{array}$ & $\begin{array}{l}40.0 \% \\
(22)\end{array}$ & $\begin{array}{l}36.5 \% \\
(31)\end{array}$ & $\begin{array}{l}37.9 \% \\
(53)\end{array}$ \\
\hline $\begin{array}{l}\text { Return } \\
\text { migrant }\end{array}$ & $\begin{array}{l}5.9 \% \\
(2)\end{array}$ & $\begin{array}{c}22.2 \% \\
\text { (8) }\end{array}$ & $\begin{array}{l}14.3 \% \\
(10)\end{array}$ & $\begin{array}{l}14.9 \% \\
(10)\end{array}$ & $\begin{array}{c}11.7 \% \\
(7)\end{array}$ & $\begin{array}{l}13.4 \% \\
(17)\end{array}$ & $\begin{array}{l}25.5 \% \\
(14)\end{array}$ & $\begin{array}{l}24.7 \% \\
(21)\end{array}$ & $\begin{array}{l}25.0 \% \\
(35)\end{array}$ \\
\hline Non-migrant & $\begin{array}{c}26.5 \% \\
(9)\end{array}$ & $\begin{array}{l}27.8 \% \\
(10)\end{array}$ & $\begin{array}{l}27.1 \% \\
\text { (19) }\end{array}$ & $\begin{array}{l}40.3 \% \\
(27)\end{array}$ & $\begin{array}{l}36.7 \% \\
(22)\end{array}$ & $\begin{array}{l}38.6 \% \\
(49)\end{array}$ & $\begin{array}{l}34.5 \% \\
(19)\end{array}$ & $\begin{array}{l}38.8 \% \\
(33)\end{array}$ & $\begin{array}{l}37.1 \% \\
(52)\end{array}$ \\
\hline Total & $\begin{array}{c}100.0 \% \\
(34)\end{array}$ & $\begin{array}{c}100.0 \% \\
(36)\end{array}$ & $\begin{array}{c}100.0 \% \\
(70)\end{array}$ & $\begin{array}{l}100.0 \% \\
(67)\end{array}$ & $\begin{array}{c}100.0 \% \\
(60)\end{array}$ & $\begin{array}{l}100.0 \% \\
(127)\end{array}$ & $\begin{array}{c}100.0 \% \\
(55)\end{array}$ & $\begin{array}{c}100.0 \% \\
(85)\end{array}$ & $\begin{array}{l}100.0 \% \\
(140)\end{array}$ \\
\hline $\begin{array}{l}\text { For total sa } \\
\text { Among males: } \\
\text { Among female }\end{array}$ & $\begin{array}{l}\text { Chi } \\
\text { Chi } \\
\text { Chi }\end{array}$ & $\begin{array}{l}\text { square } \\
\text { square } \\
\text { square }\end{array}$ & $\begin{array}{l}=12.048 \\
=9.884 \\
=6.182\end{array}$ & $\begin{array}{l}81 * * * \\
99 * * \\
79\end{array}$ & $\begin{array}{l}\text { d.f. }= \\
\text { d.f. }= \\
\text { d.f. }=\end{array}$ & $\begin{array}{l}C \\
C \\
C\end{array}$ & $\begin{array}{l}=.18579 \\
=.24411 \\
=.18174\end{array}$ & & \\
\hline
\end{tabular}


Helen Ralston

TABLE 16. MIGRANT STATUS BY FAMILY SIZE, MIGRATORY SIBLINGS, MIGRATORY RELATIVES

\begin{tabular}{|c|c|c|c|}
\hline & $\begin{array}{l}\text { Correlation } \\
\text { coefficient }\end{array}$ & $\begin{array}{l}\text { Degrees of } \\
\text { freedom }\end{array}$ & Sig. \\
\hline $\begin{array}{l}\text { Zero order correlation with } \\
\text { family size } \\
\text { Ist order partial correlation } \\
\text { sex controlled }\end{array}$ & $\begin{array}{l}.1324 \\
.1321\end{array}$ & $\begin{array}{l}379 \\
379\end{array}$ & $\begin{array}{l}.005 \\
.005\end{array}$ \\
\hline $\begin{array}{l}\text { Zero order correlation with } \\
\text { migratory sibilings }\end{array}$ & . 1964 & 206 & .002 \\
\hline $\begin{array}{l}\text { Ist order partial correlation } \\
\text { sex controlled } \\
\text { s.e.s. controlled }\end{array}$ & $\begin{array}{l}.1978 \\
.1966\end{array}$ & $\begin{array}{l}205 \\
205\end{array}$ & $\begin{array}{l}.002 \\
.002\end{array}$ \\
\hline $\begin{array}{l}\text { 2nd order partial correlation } \\
\text { sex and s.e.s. controlled }\end{array}$ & .1979 & 204 & .002 \\
\hline $\begin{array}{l}\text { Zero order correlation } \\
\text { with migratory relatives }\end{array}$ & .1331 & 206 & .028 \\
\hline $\begin{array}{l}\text { 1st order partial correlation } \\
\text { sex controlled } \\
\text { s.e.s. controlled }\end{array}$ & $\begin{array}{l}.1325 \\
.1326\end{array}$ & $\begin{array}{l}205 \\
205\end{array}$ & $\begin{array}{l}.028 \\
.028\end{array}$ \\
\hline $\begin{array}{c}\text { 2nd order partial correlation } \\
\text { sex and s.e.s. controlled }\end{array}$ & .1322 & 204 & .029 \\
\hline
\end{tabular}

\section{Conclusion}

The present research has addressed itself to the problem of accounting for any observed sex differences in the relationship between post-secondary educational aspirations and migration. The longitudinal data of the study show that post-secondary educational aspirations are in fact significantly related to migration among males but not among females. Moreover, actual continuation of education at the post-secondary level is significantly related to migration, especially ameng-males. In-general, mates-have-continued-their education in greater proportions than females, and participation of males in university education is much greater than that of females. Among those young women and young men who have continued their education, women have been able to continue their education in their community of origin in much greater proportions than men. Moreover, among males and females who have migrated for post-secondary education, the women have tended to stay closer to home (within the province of Nova Scotia) than have the males. The evidence suggests that the opportunities for post-secondary education within the province are greater for females than for males, despite the fact that a greater proportion of the girls than of the boys came from small communities. A high proportion of the young women (58 per cent) have continued their education in business college, teachers' college or nursing school. Virtually none of the young men entered such institutions. Males, who have gone to universities in much greater proportions than females, or to technical institutes, have tended to migrate for this education, and to migrate a greater distance than females. 
In terms of the opportunities for post-secondary education available in the different communities of origin, there were some communities that appear to have exercised a "holding power" on the respondents. For instance, adolescent boys and girls in Halifax had plenty of opportunity for university education; so too could the boys who lived in Halifax or Truro attend an institute of technology or agriculture without migration. Adolescent boys and girls who lived in the smaller communities had fewer opportunities and have tended to migrate for their college education and nursing or teaching training, respectively.

I have argued at the outset of this paper that the issue of post-secondary educational aspirations is different for adolescent boys and girls; that some adolescent girls may choose a career outside the home, either before or after marriage, only before marriage, or not at all; that for some young women, at least, marriage itself is an important goal. The results of the study suggest that marriage as a goal may provide the key to apparent sex differences in such variables as rates and kinds of schooling, and motives for migration. Marriage may in fact be a specific career choice for girls, (not merely a "no career" choice), a positive motivating factor in migration. Career and job choices, and the education and training associated with preparing for these careers and jobs, may well be made to fit into the anticipated marriage/mother/career role. Rosenberg (1957: 50) has noted that girls oriented to a career outside the home are more like career-oriented boys than all girls. The results of the present research show some support for Rosenberg's findings. The data in Table 13 above have presented the motives for migration of all young men and women who have moved since the Breton study in 1965. Sex differences are evident in these motives for migration. If one eliminates from the sample, however, those young women whose motive for migration was to be with boy friend or husband, the sex differences in motives for migration are very little, the most notable being in the category of wanting travel/change/ independence. and this may be a euphemism among girls for looking for a marriage partner. Table 17 presents this modified analysis of sex differences in motives for migration, when one eliminates females who migrated for boy friend/husband reasons. Moreover, for 30 per cent of the young women who are still migrants, "getting married/being with boy. friend or husband" is the explicit motive given for migration.

\section{TABLE 17. DISTRIBUTION OF MIGRANTS, RETURN MIGRANTS, BY MOTIVES FOR MIGRATION, BY SEX, WITH AND WITHOUT BOYFRIEND/ HUSBAND MOTIVES}

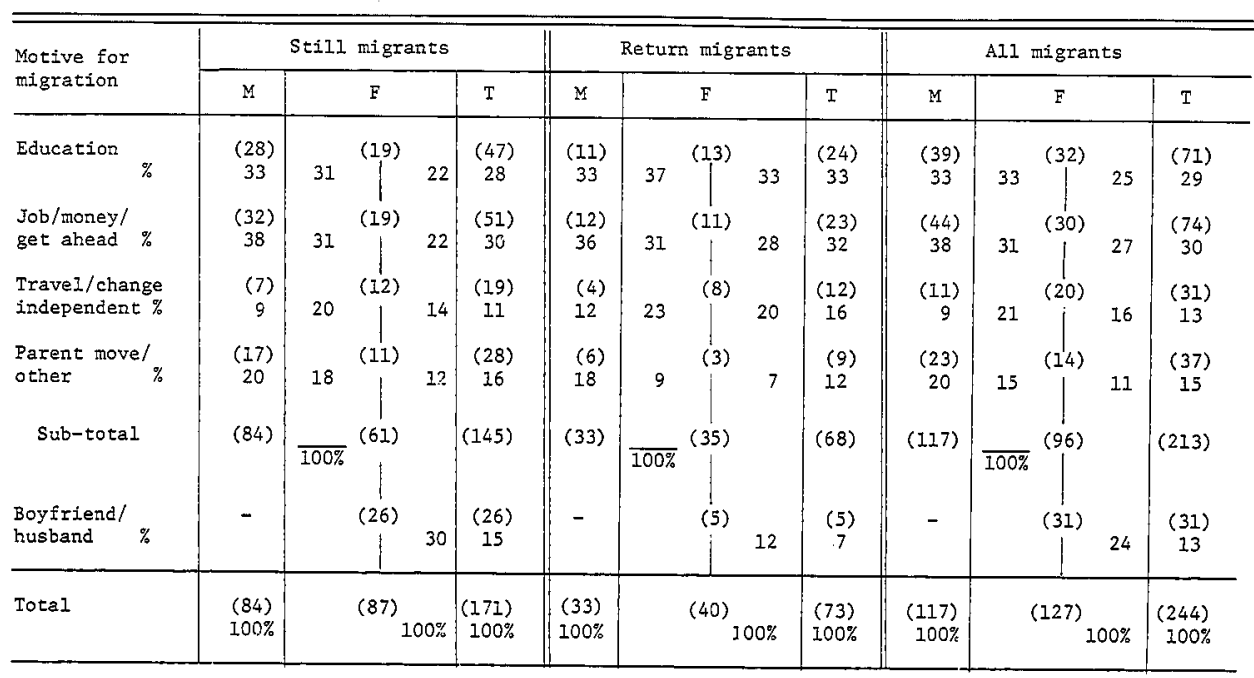


Helen Ralston

The results of this research have not provided conclusive evidence to account for sex differences in the relationship between post-secondary educational aspirations and migration. They have, however, suggested that for young women marriage is an important variable entering into the education/migration decision; that women's post-secondary educational decisions tend to be directed towards entering traditional women's occupations; that migration is a process closely related to the career goal, be it job for the young men, or job or marriage for the young women.

\section{Acknowledgments}

This paper is a revision of a working paper presented at the meetings of the Canadian Population Society, University of New Brunswick, Fredericton, June 10, 1977. I am grateful to Grace MacNab for her extensive, helpful comments on this draft, particularly for her insights on the significance of marriage as a career goal for women. I would also like to express my appreciation of helpful comments on the draft made by Ronald Cosper and an anonymous referee. The original data were gathered for my $\mathrm{Ph}$.D. dissertation, which was funded by Canada Council Doctoral Fellowships held at Carleton University.

\section{Footinotes}

1. The sample of Nova Scotia respondents used in this research is identical with the self-weighting sub-sample of three hundred and ninety one Nova Scotia secondary school students used by Raymond Breton in his analysis of the data in the Career Decisions Project conducted in 1965-'66 by Breton and McDonald (1967), in co-operation with the Federal Department of Manpower and Immigration and the Provincial Departments of Education. For more details on the Breton sample, see Breton (1972: 401-404).

2. Shryock distinguished between primary migrants, defined as "those persons who made the basic decision for themselves or their families as well," and secondary migrants, defined as "those whose migration was merely derivative from a decision made by the head of the family" (1964: 404). In this study, migrants were classified as primary migrants and secondary migrants in terms of their responses to a single item in the questionnaire, namely the item asking the main reason for migration; (see Table 13 below for the distribution of responses). There were marked sex differences in the distribution of primary and secondary migrants ( 10 per cent males as compared to 27 per cent females); nevertheless since the focus of the research is precisely on sex differences in migration, secondary migrants have been classified as true migrants.

3. The socio-economic status origin of the respondents was measured by the occupational status of the father at the time of the original Breton survey in 1965; the data from the 1965 questionnaire were used to measure father's occupation. The respondents were classified as follows, in terms of their fathers' occupational status in relation to the Pinco-Porter (1967) scale of occupational prestige:

$\begin{array}{ll}\begin{array}{l}\text { Professional } \\ \text { Proprietors, managers, and officials, large } \\ \text { Semi-professional } \\ \text { Proprietors, managers, and officials, small }\end{array} & \left\{\begin{array}{l}\text { High } \\ \text { socio-economic } \\ \text { status origin } \\ \text { Clerical and sales } \\ \text { Skilled }\end{array}\right. \\ \begin{array}{l}\text { Semi-skilled } \\ \text { Unskilled }\end{array} & \begin{array}{l}\text { Mocio-economic } \\ \text { status origin }\end{array} \\ \text { Low } \\ \text { socio-economic } \\ \text { status origin }\end{array}$

\section{References}

Beijer, G., N.H. Frijda, B.P. Hofstede and R. Wentholt. 1961. Characteristics of Overseas Migrants. The Hague: Government Printing and Publishing Office

Blau, Peter M. and Otis Dudley Duncan. 1967. The American Occupational Structure. New York, London: John Wiley and Sons. 
Breton, Raymond. 1972. Social and Academic Factors in the Career Decisions of Canadian Youth: A Study of Secondary School Students. Ottawa: Information Canada.

Breton, Raymond and John C. McDonald. 1967. Career Decisions of Canadian Youth: A Compilation of Basic Data. Ottawa: Department of Manpower and Immigration.

Canada. Statistics Canada. 1972. Advance Bulletin. 1971 Census of Canada. Urban and Rural Population. Catalogue \#92-755.

1972. Advance Bulletin. 1971 Census of Canada. Nova Scotia Population in Thousands. Catalogue \#92-730.

1975. Education in Canada: A Statistical Review for 1971-72 and 1972-73. Catalogue \#81-229.

Connor, Desmond Maurice. 1963. Toward a Theory of Selective Migration and Residence. Unpublished Ph.D. Dissertation. Cornell University.

Davis, Kingsley. 1949. Human Society. New York: The Macmillan Company.

DeJong, Gordon and Zafar M.N. Ahmad. 1976. Motivation for Migration of Welfare Clients. In Anthony H. Richmond and Daniel Kubat (eds.), Internal Migration: The New World and the Third World. Beverly Hills and London: Sage.

Elizaga, Juan C. 1972. Internal Migration: An Overview. International Migration Review 6: 121-146.

Festinger, L. 1957. A Theory of Cognitive Dissonance. Stanford: Stanford University Press.

George, M.V. 1970. Internal Migration in Canada: Demographic Analyses. Ottawa: Queen's Printer.

1971. Estimation of Interprovincial Migration for Canada from Place of Birth by Residence Data, 1951-1961. Demography 8: 123-139.

Glaser, William A. and G. Christopher Habers. 1974. The Migration and Return of Professionals. International Migration Review 8: 227-244.

Goldsmith, Harold Frank. 1962. The Meaning of Migration: A Study of the Migration Expectations of High School Students. Unpublished Ph.D. Dissertation. Michigan State University.

Hall, Oswald and Bruce McFarlane. 1962. Transition from School to Work. Research Programme on the Training of Skilled Manpower, No. 10. Ottawa: Queen's Printer.

Hawley, Amos. 1950. Human Ecology. New York: The Ronald Press Company.

Lee, Everett. 1966. A Theory of Migration. Demography 3: 47-57.

Lucas, Rex A. 1971. Minetown, Milltown, Railtown. Toronto: University of Toronto.

Marchak, M. Patricia. 1977. The Canadian Labour Force: Jobs for Women. In Marylee Stephenson, Women in Canada. Don Mills: General Publishing Company.

Marckwardt, A. McC. 1968. Differentials of Recent Internal Migration in the United States. Unpublished Ph.D. Dissertation. University of Michigan.

Meissner, Martin. 1977. Sexual Division of Labour and Inequality: Labour and Leisure. In Marylee Stephenson, Women in Canada. Don Mills: General Publishing Company.

Pike, Robert M. 1970. Who Doesn't Get to University and Why: A Study on Accessibility to Higher Education in Canada. Ottawa: Runge Press.

Pineo, Peter C. and John Porter. 1967. Occupational Prestige in Canada. Canadian Review of Sociology and Anthropology 4: 24-40.

Pyke, Sandra W. 1977. Sex-Role Socialization in the School System. In Richard A. Carlton, Louise A. Colley, Neil T. MacKinnon (eds.), Education, Change, and Society: A Sociology of Canadian Education. Toronto: Gage Publishing Company. 


\section{Helen Ralston}

Rosenberg, Morris. 1957. Occupations and Values. Glencoe: The Free Press.

Schwarzweller, H.K. 1959. Value-Orientations and Occupational Choice. Rural Sociology 24: 246-256.

Sewell, W.H. and Alan M. Orenstein. 1965. Community of Residence and Occupational Choice. American Journal of Sociology 70: 551-563.

Shryock, Henry S., Jr. 1964. Population Mobility within the United States. Chicago: Community and Family Study Center, University of Chicago.

Shryock, Henry S., Jr., and Elizabeth A. Larmon. 1965. Some Longitudinal Data on Internal Migration. Demography 2: 579-592.

Simmons, Alan B. and Cardona G. Ramiro. 1972. Rural-Urban Migration: Who Comes? Who Stays? Who Returns? Internal Migration Review 6: 166-181.

Stephenson, Marylee (ed.). 1977. Women in Canada. Rev. Ed. Don Miils: General Publishing Company.

Stone, Leroy O. 1974. What We Know About Migration Within Canada - A Selective Review and Agenda for Future Research. International Migration Review 8: 267-281.

Stouffer, Samuel A. 1940. Intervening Opportunities: A Theory Relating Mobility and Distance. American Sociological Review 5: 845-857.

1960. Intervening Opportunities and Competing Migrants. Journal of Regional Science 2: 1-26.

Synge, Jane. 1977. The Sex Factor in Social Selection Processes in Canadian Education. In Richard A. Carlton, Louise A. Colley, Neil J. MacKinnon (eds.), Education, Change, and Society: A Sociology of Canadian Education. Toronto: Gage Publishing Company.

Taylor, R.C. 1969. Migration and Motivation: A Study of Determinants and Types. In J.A. Jackson (ed.), Migration. Cambridge: Cambridge University Press.

Thomas, Dorothy Swaine. 1938. Research Memorandum on Migration Differentials. Bulletin \#43. New York: Social Science Research Council.

1941. Social and Economic Aspects of Swedish Population Movements, 1750-1933. New York: The Macmillan Company.

Tilly, Charles and C. Harold Brown. 1967. On Uprooting, Kinship and the Auspices of Migration. International Journal of Comparative Sociology 8: 139-164.

Turner, Ralph H. 1964. Some Aspects of Women's Ambition. American Journal of Sociology 70: 271-285.

Whyte, Donald R. 1967. Social Determinants of Inter-Community Mobility: An Inventory of Findings. Canadian Review of Sociology and Anthropology 4: 1-23. 